University of Louisville

ThinkIR: The University of Louisville's Institutional Repository

Electronic Theses and Dissertations

1938

\title{
Joseph Altsheler : his contribution to American fiction for boys.
}

Ona Belle Demaree 1898-1951

University of Louisville

Follow this and additional works at: https://ir.library.louisville.edu/etd

Part of the Children's and Young Adult Literature Commons

\section{Recommended Citation}

Demaree, Ona Belle 1898-1951, "Joseph Altsheler : his contribution to American fiction for boys." (1938). Electronic Theses and Dissertations. Paper 1778.

https://doi.org/10.18297/etd/1778

This Master's Thesis is brought to you for free and open access by ThinkIR: The University of Louisville's Institutional Repository. It has been accepted for inclusion in Electronic Theses and Dissertations by an authorized administrator of ThinkIR: The University of Louisville's Institutional Repository. This title appears here courtesy of the author, who has retained all other copyrights. For more information, please contact thinkir@louisville.edu. 


\title{
University of Louistilie
}

\author{
Joseph Altshelex
}

His Contribution to American Fiction for Boys

\author{
A Dissertation \\ submitted to the Faoulty \\ Of the Graduate School of the University of Loulsville \\ In Partial Fulfillment of the \\ Requirements for the Degree \\ of lastex of Arts
}

Department of Inglish

by

Ona Belle Demaree

Year

1938 
Name of student:

Title of Thesis: Joseph Alteheler-His Contribution to American Fiction for Boys

Name of Director:

Approved by a reading cormittee composed of the following members:

Representative of the Inglish Department;

Date: $3 \operatorname{kan} 25,198$ 


\section{Table of Contents}

Part One: Backeround

The Development of American Fiction for Boys I

Joseph Altsheler and His Books for Boys 19

Part Iwo: Analyolo

Altghelex's Fiotional Formula for Characterization 36

Alshelex's Fictional Formula for story Yovement 55

Alshelex's Treatment of the American scene 73

Ideology Ixpressed in Altahelex's stories 100

Conolusion

Altahelex's Contribution to Boys' Ilction

125

Bibliography

118 
Part One: Background

Chapter One

The Development of American Iiction for Boys 
The Development of American Fiction for Boys

To gauge the contribution of Joseph $A$. Altsheler to boys' flotion in America requires a backeround sketch of the development of American fiction for boys as well as a sketoh of Altsheler's own background.

The development of American flotion for boys still awalts scholarly study. Approaches to 1 t are made in the syllabus by Flve B. mith somewhat ambitiously entitled the History of Chizaren's Itterature ${ }^{l}$ and in the study of jurentle fiction before 2850 in $41 \mathrm{~s}$ Halsey's Porrotten Books of the American Iurgerx. ${ }^{2}$ These are the only attempts at a connected picture. For the period after 1850, the pioture must be pleced out on the basis of scattered magazine articles and a sampling of the fiction.

Before 1822, there was no original literature for children in the United States. There rere jurenile books, but they either "followed Inglish models or were

Ionith, Flva 8., The History of Children's Iiterature; :

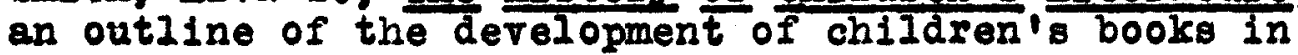
Ingland and America up to 1900. The American Ifbrary Assoclation, 1937

2

2 Hal sey, Rosalie V., Forrotten Books of the Amerioan Nursery, Charles I. Goodspeed and Company, 1911 
actually the work of Inglish writers." ${ }^{1}$ They were of three types:: religious books, educational books, and books of amusement. The religious books were catechisms and tokens, or stories, recounting the deeds of pious and precooious children. 2 The books of the educational type were "lessons" designed to combine sel1glous and educational training. 3 The:so-called books of amusement were reprints of the Fnglish chap books of John Newbexy.

1

Jordan, Al10e M., Children's Books in America: The Pixst Hundred Years", The Horn Book Harazine, 10 $(1934), 9-19$

2

The first book of this type was entitled Mlk for Bahes and was written between 1641 and 1675 by John Cotton to meet the request of the "General corte" that the elders of the Massachusetts settlement make a catechiam for the instruction of youth in the ground of religion. This was the first book of any kind witten and printed in America for children.

3

The flrat book of this type was Cotton Mather's Good Iessons for Children; or Instruction Provided for a Iittle son to Iearn at school when Iearning to Read (1706). Its purpose was to have the child Improve in goodness at the same time that he improves in reading".

4 John Newbery (1713-1767) wrote about fifty original little books. They were moral tales and fables witten for the purpose of combining instruction and amusement. Their preaching was different from that of former times. Hitherto, the fear of the lord had wholly ocoupied the author's attention when he composed a book; now materlal welfare was dwelt upon. The good boy'g reward came to him when he was made Loxd Jayor of London. The benefits of leaxning were also amphasized. 
The first original contribution to ohildren's litexature in America was A Vialt from St. Hicholas, the rhymed story of Santa claus and his reindeer written by Clement Clarke Hoore of New York in December, 1822. Ux. Woore, who was the son of the President of columbia college and who was a student of oriental and classical literature, wrote the poem for his own children. subsequently, a friend of the family sent it to the Troy Sentinel where it was published anonymously on December 23, 1823. It seoms to be America's only real contribution to the 11terature of Christmas. To it we owe the American conception of the physical qualities of the "right jolly old elf" whom Mr. Hoore created in the likeness of a fat little Dutchman often seen around his home. The American danta Claus owes his sleigh, his eight reindeer, his furs, his pipe, and his method of entrance by way of the chimney to Wr. Hoore's poem.

This first piece of imaginative literature written for chllaren by an American does not seem to have influenced the general development of children's literature in this country.

The broad outline of the development of jurenile

${ }^{1}$ Halsey, Rosalie V., Forrotten Books of the American Irurgery, Charles E. Goodspeed and Company, 1911 
literature in America may be followed in the development of boys' fiction. This is the result of $s i x$ definite influences.

The first of these influences was that of the American sunday-school with its 1 ibraries ${ }^{2}$ and its publication societies. 3 The rewards offered to children for wel1-prepared lessons and for the use of sunday-school librarles created a demand for children's books while the standards set up by the publication board of the American Sunday School Union had much to do with determining their character. 4 so great was the influence of this board upon parents that the correct and approved child's story of this period, whether

The first sunday-achool in Amexica was organized in 1791, ten years after the organization of the first sunday - school in England.

2 The first Sunday-school library in America was established in Philadelphia in 1827 and numerous others folloried.

3

Several of these societies formed the American sunday School Union whose board of publications passed upon the merits of manuscripts and edited those which proved acceptable.

4 "The tales had to keep absolutely within the bounds of religion. Hany were the stories found lacking in direct religious teaching, or returned because religion was not vitally connected with the plot, to be rewritten or sent elsewhere for publication. (Forrotten Books of the American Nursery by Rosalie V. Halsey, p. 202T 
Issued under religious auspices or not, showed an educational, a moral, and a religlous tendency. American flotion for boys had its beginning in the storles of boy heroes which grew out of this sundayschool influence. The first of these tales were those of Samuel G. Goodrich which had all the elements of the sunday-school literature. H1s inspiration to write them was furnished by the religlous stories written by Hannah Kore in cooperation with the first sabbath day school in mgland ${ }^{2}$ and he was writing for a public which belleved that "the only excuse for fiction in a godly family was that it conreyed information and a pious moral." 3 As a result, his tales contain either much information and little story or much moral and little story. He makes no attempt at characterization but merely allows the children in his tales to relate to

${ }^{1}$ Peter Parlex's Tales About America (1828), followed by rales from Europe and one hundred other tales

2 Goodrich, Samuel Griswold (pseud. Peter Parley), Recollections of a Iifetime, 2 v. Milier, orton, and Milil$\operatorname{gan}, 1856$

3 Stevens, William 0lirer, "Uncle' Peter Parley", st. Nicholag, V. 53 (1925), 78-81 
each other historical information about the places they visit during their travels. Yet some of his tales do contain elements of the modern boys' story. Besides using boys as the central characters, they present parts of the American scene, ${ }^{1}$ introduce American nature descriptions, ${ }^{2}$ give accounts of adrentures with Indians on the American frontier, and furnish historical information about places in America. The immense popularity of the books resulted from these elements of the American scene. 3

The stories of American boys written by Jacob Abbott between 1832 and 1879 were also contributions to the sunday-school literature which contained elements of the modern boys' story. His Rol20 Bookg, Franconia Stories, Rainbor and Iucky Stories, and his other tales

'Parley's Tales were the first children's books with an American setting ( American Nursery, p. 214)

2

Up to this time there had been a total lack of American nature descriptions. Olivex Wendell Holmes is quoted as having remarked that in the literature of his boyhood no birds or flowers famlliar to him were ever mentioned. After the appearance of Parley's books, the children's annuals and periodicals began to abound in stories of local color (Forsotten Books of the American Nursery, p. 201)

3 since the Revolution there had been a growing demand for these American elements in children's stories and it is estimated that seren million of Peter Parley's "Histories" and "Tales" were sold before the admlration for the style and quality waned. 
satisfied the populax demand for moral stories about good boys who were "steady, sensible, sagacious, not troubled with languor or imagination, and who possessed domestic and agricultural virtues." ${ }^{2}$ At the same time, their setting is American ${ }^{2}$ and they introduce two new elements found in the modern boys' story. The first of these is the use of natural life-like characters and the second is the use of the story series. No definite person stood out in the Peter Parley books, but in those of Jacob Abbott there were many individual chlldren whose names became household words 3 and "whose blameless adventures held and delighted more than one generation of boys and girls." 4

The second influence which helped to shape the development of American fiction for boys was the reaction of children againgt the sunday-school literature.

1 From an article by an unknown author in the North American Review for January, 1866

2 The scene of the Rollo Books, the Franconia stories, and some of the other tales was laid in the country nei ghborhoods of New Ingland.

3 Some of these names are: Ro110, Jonas, Beechnut, Iucy. 4 Jordan, Alice L., "The Childaren of Jacob Abbott", The Horn Book Marazine, 10 (1934), 163-78 
The healthy-minded, vigorous child often turned in disgust from the sunday-school library to search among the volumes of his father's bookshelves for life-like stories that were free from preaching. Among the earliest American novels to be thus taken over by boys were Cooper's novels of the frontier (1827-1841), Robert Montgomery Bird's Nick of the Woods (1837), James Kirke Paulding's The Dutchman's Fireside (1831) and Westward Hod (1832) and D. P. Thompson's Green Mountain Boys (1839). Later, they read John Esten Cooke's novels of the frontier and Theodore Winthrop's stories of adventure. Cooke's novels were in the tradition of Cooper and the favorites with boys were Leather Stocking and s11k (1854) and The Iast of the Forresters (1856). The favorite Winthrop stories were John Brant (1862), a narrative of adventure in the far West, and The Canoe and the saddle (1863), a story of the Northwest.

When the "dime novel" started on its career about 1860, many of these stories were taken over by boys. These books told stories of the old frontier of Cooper and of the trans-Mississippi border with its Mexicans, bandits, troopers, and Indians. They introduced as heroes such frontiersmen as KIt Casson, William 5 . Cody (Buffalo Bili), Daniel Boone, and Simon Kenton. 
The tales were conversational, exciting, and devoted to the doctrine of poetic justice. ${ }^{2}$ Among the most popular of these stories were the frontier narratives of Edward s. Ellis. Of one of his books, seth Jones or The Captive of the Frontier, Bllis is sald to have sold 600,000 copies in half a dozen languages.

As the West filled up and the fuvenile imagination turned from the forest to the town, "dime novels $n^{2}$ in the form of detective stories were produced in large numbers and they, too, were approprlated by boys.

This reaction of the children against the jurenile stories approved by the Sunday School Union exerted a strong influence upon the development of boys' fiction because it indicated types of storles which writers for boys must produce if they expected them to be popular.

These stories which boys had appropriated were of three types. They were romantic stories of the old frontier like those of cooper and Cooke, realistic tales of the frontier and settlement like Bird's Nick of the Woods and Paulding's Dutchman's Fireside, and sensational

\footnotetext{
${ }^{1}$ Van Doren, Carl, The American Novel, p. 110-111 2

The "dime novel" continued to be popular in America until it was forced to give place to the more exciting moving picture in 1900
} 
machine made stories of the "dime novel" type. These three types had two elements in common. One was rapid action and the other was a hero who was brave and strong and who struggled against fearful odds, undertaking deeds of great daring, and winning out in the end. These types and elements are represented in the boys' fiction of to-day.

The third influence was the reaction of serious writers of fiction like Thomas Bailey Aldrich and Mark Twain against the "good boy" stories of the sunday-school 1ibraries. Aldrich's Story of a Bad Boy (1870) was welcomed as a sincere account of the experiences of a real boy, but its popularity was eclipsed by the more exciting Adventures of Tom Savrex (1876) and Adventures of Hucklebersy Finn (1887). Twain's stories established the tradition of the "bad boy" story in American juvenile fiction. However, other jurenile writers of this period who have attempted this type of stoxy lacked the imagination and artistry to produce anything sufficiently vital and gripping to rival kaxk Twain's books in popularity.

The fourth influence was the development of public education in America. Between 1855 and 1898, "education was becoming the central fact in American social 
Iife." ${ }^{2}$ The people were becoming willing to tax themselves for the education of all grades from the lowest to the highest. Men of wealth were developing the habit of making contributions for the support of education. Between 1870 and 1890, public funds for educational purposes almost trebled and the public school enrollment increased at the same rate. By 1900, there were thirteen milition children attending the public schools and the number of public high schools had increased from 100 in 1860 to 6,000 in 1900 with a regultant increase in literacy. By the latter date, many states had fully supported public educational systems from the elementary school to the University. With this increase in literacy came an increased interest in children's books and a greater demand for them. The fifth influence was the passage of the International Copyright Iaw in 1891. This law protected forelgn works from piracy and freed the American markets so that it was possible for books by American authors to sell at a fair price. The mass production of jurenile books which began after this time was one

1 Dickingon, Thomas H., The Haking of American Iiterature, The Century Co., Ter York, 1932 
result of the encouragement given to American writers by the passage of this law.

The sixth influence was the growing interest in boys' clubs which began during the late nineteenth century and led to the organization of the Boy scouts of America in 1910. This interest in the work and play of boys resulted in a greater interest in writing boys' books and in the use of the Boy scout 1deology as one of the elements in boys' fiction. This ideology is expressed in Dan Beard's statement of his own mission and in the eleven points of the scout Iaw. ${ }^{2}$ Modern boys' fiction is a result of these six inIluences and includes elements of the "good boy" story of Bunday-school Iiterature, of the "bad boy" story of Aldrich and Mark Twain, of the adult fiction appropriated by boys, and of the Boy scout 1deology. It runs

${ }^{1}$ Dan Beard, a member of the executive board of The Boy Scouts of America, says, in an article in Mentor, August, 1927, "If I have a mission, it has been to bring the city boys into the open and where that was impracticable, to bring a bit of the life of the open to the city boys."
2(1) A scout is trustworthy
(2) A scout is loyal
3) A scout is helpful
4) A scout is friendly
5) A scout is courteous
(6) A scout is kind
(7) A scout is obedient
(8) A scout is cheerful
(9) A scout is thrifty
(10) A scout is brave
(11) A scout is reverent 
to stories of several types, the most important of which are: "the bad boy" story, the success story, the story of Indian life, the Western cowboy story, the story of woodscraft, the story of college and campus 11fe, and the historical romance-all of these manufactured in large quantities.

The most popular of the "bad boy" stories are Booth Tarkington's stories of boylsh pranks, the Penrod stories, and Iittle Orrie (1933).

The success atory is a combination of the Sundayschool story and the "dime novel". It is always the story of a "good boy" who achieves sensational success in an incredibly short time. Usually the "good boy", who starts out extremely poor and soon becomes immensely rich, is contrasted with a rich boy who is arrogant and dishonest and who is reduced to porerty as a punishment for his sins. The stories of Horatio Alger (1832-1899) are the best examples of this type of fiction for boys which was extremely popular during the late nineteenth century.

Since the stories of woodsoraft ${ }^{1}$, the stories

1

Ernest Thompson Seton's Two Iittle Savases (1911) is an example 
written about boy scouts, ${ }^{1}$ and the stories of Indian life are used as vehicles for the Boy scout 1deology, they have more of the elements of the "good boy" stories of the sunday-school literature than of the "bad-boy" stories of the middle nineteenth century. In the stories of Indian 11 fe there is the appeal to the boy's romantic interest in the Indian as well as to his love of the outdoors. 2

The American cowboy story is a type whose leading character is a combination of the Boy scout and the indomitable hero of the "dime novel". One of the latest of these stories is Look--See With Uncle Ben (1938) by Will James. It illustrates the tendency of the modern boys' story to emphasize courage and optimism in the

${ }^{1}$ Many stories written about Boy Scouts are condemned by Boy scout librarians because of their gross exaggerations. An example of the story of this type approved by them is The Boy Scout Crusoes (1916) by Edwin C. Burritt. Other Boy Scout stories approved by Boy Scout librarians are William Heyliger's Don Strong of the Wolf Patrol and Don Strons--Patrol Leader

2

Many of the stories of Indian life are the result of thorough study and firsthand experience. One example is Queer Person (1930) by Ralph Hubbard who is a special instructor in Indian lore for the Boy scouts of America. His story of the Blackfeet Indians grew out of his study and experiences while living on a government homestead near the Crow Reservation in Montana and, later, on a ranch in Colorado. 
face of hardships and dangers, thus making the hero essentially a Boy scout.

A more realistic type which also emphasizes standards set up by the Scout Law is the modern story of High School and college athletics. The Iron Duke by John R. Tunis which was awarded the $\$ 250$ offered by the Wew York Herald Tribune for the best book puilished this year for older children is a book of this type. Unlike other boys' stories of college life, it shows the hero in contact with classes as well as with sports and tells a realistic story of the character development of its hero during his years at Harvard. Ralph Henry Barbour is another contributor to this type of juvenile fiction. He spends his winters in Florida and his summers in the North, always keeping in close touch with boyg' spoxts and the men behind them. He has written more than seventy stories of High School and college athletics. The Boy scouts of America have indicated their approval of his books by including them in Every Boy's Iibrary.

Another type of fiction which juvenile writers have contributed is the historical romance. These stories have many of the elements of the historical romances which were approprlated by boys during the 
middle nineteenth century. They are action stories with a background of historical fact and incident and their heroes are skilled woodsmen whose deeds of daring rival those of the old soouts of the frontier. One of the largest contributors to this type of boys' fiction was Joseph A. Altsheler. 
Chapter Two

Joseph Altsheler and His Books for Boys 
Joseph Altsheler and His Bookg for Boys

Alshelex's background explains his writing the type of story that he did. He was born in Hart County, Kentucky on Apri1 29, 1862. His father, tho had come to this country in early manhood from Bingenon-the-Rhine, seems to have been a man of exceptional interests. His mother, who had been Miss Lucy snoddy of Barren County, Kentucky, was descended from the Virginia and Kentucks borderers. During his boyhood, she told him over and over the legends of Danlel Boone, Simon Kenton, James Harrod, Benjamin Logan, and other woodsmen and Indian fightexs. These stories stimulated his imagination, and "he would lie on his back by the hour out there in Daniel Boone's country, letting his mind dwell on the pioneer tales of America until they came to have for him the fascination that tales of Greece have for other minds." ${ }^{2}$ Both Northern and southern veterans of the Civil War were amons his father's friends and the boy often heard them tell of their personal experiences during the war. ${ }^{2}$ His

1Moore, Annie Carroll, Joseph Altsheler and American H1story, American Library Association, New York, 1920 2 Among them was General Simon Boliver Buckner, a native of Hart County, Kentucky. 
interest in the frontier legends and in stories of the war sent him to his father's library where "he found much to satisfy his taste for history." ${ }^{2}$

Later, he had other contacts which probably increased his interest in American history. While attending Iiberty College at Glasgow, Kentucky, he lived with his grandmother and she talked much about the Civil War. Aftex leaving Vanderbilt University ${ }^{2}$ and going to Louisville, Kentucky, to do newspaper work, he lived in the same apartment hotel with General Don Carlos Buell who told him of his experiences during the war.

His many years of newspaper work gave him specific training in writing. From 1885 to 1892, he was a membex of the staff of the Iouigville Courier Journal where he held, successively, the position of reporter, c1ty editor, dramatic editor, and editorial writer.

1

Inquiries concerning the contents of this library elicited no information from members of Mr. Altsheler's family. Hawkins snoddy in a paper written for the Historical soclety of Barren County, Kentucky refers to it as "a fine library" from which neighbors were in the habit of borrowing books to be "passed around from one to another."

2 In 1885, when the death of his father made it necessary for Wr. Altsheler to leave Vanderbilt without his degree, he went to Louigville and obtained a position in John P. Morton's Book store. Not liking the work there, he secured the position with the Courier Journal. 
In the last position, he was associated for four years with Henxy Watterson, founder of the Courier Journal. In 1892, he went to New York where he joined the staff of the New York World. He worked his way up to the editorship of the thrice-a-week edition, the position which he held until 1919. By 1897, when his first book was published, he had had twelve years of newspaper experience.

Between 1897 and 1907, he wrote eight historical romances, ${ }^{1}$ two reporter stories, ${ }^{2}$ and sereral magazine stories. 3 Members of his family have no knowledge of any unpublished material.

The historical romances intended for adults are of no importance as contributions to American fiction. None of their characters are lifelike, and no character

The Sun of Saratoga (1897), A Soldiex of Manhattan (1897), A Herald of the West (1898), The Last Rebel 1899), In Ciroling Camps (1900), In Hostile Red $\left(\begin{array}{l}1900 \\ 1903\end{array}\right)$, The Wilderness Road (1901), Before the Dawn

2 Guthrie of the Times (1904). The Candidate (1905)

3 See Bibliography for complete list 
development is shown. The plots are clumsy and the story movement is slow and monotonous. The least readable of them all are the three stories of the Revolutionary War Period.

The elements which make the other five ${ }^{2}$ more worth-while are those which afterward made his boys' storles successful. One of these elements is the background of authentic historical information. Another is a picture of the American scene during the period represented by each story. The third and most important is the vitality of these parts of the stories which grew out of his boyhood experiences in Kentucky.

The story in which these elements are most evident is The Wilderness Road (1901) which pictures the movement for expansion at the end of the eighteenth century when the men of Kentucky and the old frontier were pushing northward and westward. It tells of

${ }^{1}$ The Sun of Garatoga (1897), In Hostile Red (1900), Iy captive (1902)

2 A Soldier of Manhattan (1897), A Herald of the Hest (1898), In Circling Camps (1900), The Wildernes Road (igo1), Before the Dawn (1903) 
St. Claif's defeat by the Indians of the Northwestern Confederation and of Anthony Hayne's victory over them. The scene moves from Danville, Kentucky, to Louisville, from there into the Northwest, and finally to Philadelphia. The hero is a man who loves the forests of Kentucky as Altsheler must have loved them. He "knows the wilderness and does not fear it, for the breath of the wilderness is sometimes the breath of God." 1

The reporter stories are closer to realism than the historical romances.

Guthrie of the Times (1904), which may be autobiographlcal, is the story of a young reporter sent by the Louigville Tines to Frankfort to report a seasion of the Kentucky Legislature. The young man's duties take him into the mountains where circumstances force him to become one of the actors in a feudist drama. The story emphasizes the duties of the reporter as historian and critic. It is also the "success story" of a young man of keen intellect, resourcefulness, and courage.

$1_{\text {The Wilderness Road, p. } 35}$ 
The Candidate (1905) is a story of a Presidential campaign told from the view point of a correspondent for the New York Gezette who travels with the candidate's party. It is the story of the ultimate success of a candidate who refuses to be influenced by political bosses and who takes time, in the midst of an arduous campaign, to perform deeds of chivalry and kindness.

The contributions to magazines consist of tales of the Civil War, the Revolutionary War, and Indian wars; of stories of life on the frontier; of accounts of the experiences of office holders and candidates for office; and of one article which is autoblographical. One of the most realistic of these stories is the tale of the Civil War called, At the Twelfth Hour; A Tale of a Battle, ${ }^{1}$ (1898). It tells of a gaunt religious widow who, from her cabin in the southern mountains, watches a battle raging. Bearing water to the wounded among the flames, she finds her youngest son and carries him to her cabin to nurse him back to life. The emphasis, in this story, upon the

" "At the Twelfth Hour: A Tale of a Battle", Atlantic Monthly, 82 (1898) 541-58 
horrors of war indicates that "perhaps Altsheler was influenced by stephen Crane's Red Badge of Courage (1895).1 Like Crane, Altsheler was one of the first writers to treat the Civil War from a non-partisan point of view. This he does in both of his short stories about the Civil War.

Perhaps his historical romances were Altsheler's means of escape from realism. Ifttle autobiographical material is arailable, but one article which he published in Haxpex's in 1906 indicates a longing to get away from the perplexing problems and doubts of metropolitan life into the optimism and complacency of the Valley of Democraoy. In this article, What the Home-Comerg Sew, ho writes of a risit which he has just made to Kentucky. He says:

The New Yorkers, as soon as they crossed the Allegheny Kountains, whether at a Northern or a southern point, seemed to breathe a different atmosphere and to come into contact with a wholly fresh and buoyant spirit. In New York,

1 Smith, Rebecca Washington--The Civil War and Its Aftermath in American Piction, 1861-1899, Chicago University, August 1932 
the talk was all of graft, of corruption in government, corporation, and individual. Insurance companies were rotten, the papexs swarmed with accounts of crime, and every day in the metropolis three or four recently im-

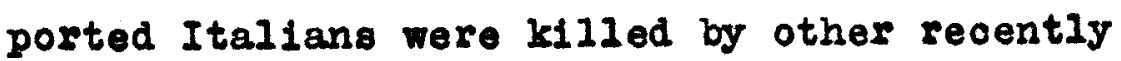
Imported Italians. Inglishmen and Scotchmen were writing to the press telling how they ordered things in Great Britain, and one who did not carefully preserve his sense of proportion was 11kely to despals of the republic. Amerlcans in New York cowered before European opinion, and the reading classes wondered what Henry James was oolng to say about us next. Beyond the shadow of New York, the changes were quiok and absolute. The homecomers were once more in indomitable, optimistic, republican America, republican to the core, prosperous as it never was before, happy in the present and expecting a greater progress in the future.

What pleased the home-comers most was the Intenge Amerioan spirit throughout the whole Mississippi ralley. It showed itself in the 
pride the people have in their own country and in their confidence that it is the best. While Hamlin Garland, Frank Norris, and Theodore Drelser were facing the social and economic problems of theix own time, Altsheder was keeping alive his belief in the old America and its assumptions by writing romances of the Civil War and reporter stortes deroted to the dootrine of poetio justice.

In the historical romances, he was following one of the trends of his own time. During the deoades between 1890 and 1910, dozens of historical novels were published and some of them were extremely successful. The popularity of Harold Frederic's In the Vallex ${ }^{2}$ (1890) and of Stephen Crane's Red Badre of Courare (1895) may have led Altgheler to hope that his romances of the Civil War, the Rerolution, and the French and Indian War would be equaliy successful. But neither the historioal romances nor the reporter stories were popular and he turned next to fiction for boys.

H1s first boys' book, The Young Trailers (1907), was written for his ow son who was then twelve years

${ }^{1}$ A naxrative of Iife along the Mohawk at the time of the Frenoh and Indian War 
of age..$^{2}$ Pexhaps his vialt to Kentucky in 1906 influenced him in trying to pass on to his son something of his ow love for the woods and an appreclation for the legends and tales of the western frontier which his mother and grandmother had told to him.

His decision to wrtte a book for boys may have been due in part to the widespread interest in boys and their work and play. The Young Trailers was published during the year of President Rooserelt's endorsement of Dan Beard's scout work. Beard had organlzed his "Sons of Danied Boone" in Kentucky in 1905, and by 1910, when The Boy Soouts of America was incorporated, there were in America thirty-Beven different organizations representing boys' work.

Perhaps the deepest motivation for The Youns Trailers lay in Altsheler's love of the rnods, no doubt revired by his visit to Kentucky in 1906. Its heroes, twelve-year-0ld boys in a backwoods Kentucky settlement in 1774, love the woods as Altgheler did and do the things which, in his boyhood, he probably longed to do. The following description of one hero

'ux. Altgheler's widow, Mrs. Ballie B. Altsheler, writes, "In 1907, he wrote The Young Irailers for our son." 
is characteristio of the author:

He (Henry Ware) could lie peacefully in the shade of a tree for an hour at a time, dreaming of rivers and mountains farther on in the wilderness. He felt a kinship with the wild things. Once as he lay perfectly still with his eyes almost closed, a stag, perhapg a brother of the one he had killed, cam and looked at him out of great soft eyes. It did not seem odd at the time to Henry that the stag should do so; he took it then as a frlendly act, and, lest he should alarm this new comrade of the wnods, he did not stir or eren raise his eyelids. The stag gazed at him a few moments and then, tossing his great antlers, turned and walked off in a graceful and dignified way through the woods. Henry wondered where the deer would go and if it would be far. He wished that he, too, could roam the wilderness so lightly, wandering where he wished, having no cares and beholding new scenes every day.

The Young Irailers was so successful that Altsheler wrote five other stories in which he told of the adventures of the same heroes after they had become skilled foresters who could render an invaluable service to 
pioneer settlers. In these books, the author carried out his purpose to "give the boys a picture of frontier Iife and to show the immense hardships and dangers endured by our people as they passed through the wilderness from ocean to ocean. ${ }^{1}$

The popularity of these six books is attested by the demand of their readers for more Young Trailer stories. In response to this demand, Altsheler wrote Keopere of the Trail in 1916 and The Breg of the Woode in 1917. These books were placed third and fourth in the series, but they add nothing new to the story and only slow up the morement.

Between 1907 and 1912, when the first six of The Toung Trailers were publlshed, Altsheler also wrote three western stories for boys ${ }^{2}$ and one storv intended for adults. 3 Historical incident forms part of the

The Forest Runners (1908), The Free Rancers (1909), The Riflemen of the ohlo (1910), the Scouts of the Valley (1911), The Border Watch (1912)

I Irom Author's Preface to The Border Watch (1912)

2 The Iast of the Chiefs (1909), The Horsemen of the Plains (1910), The Quest of the Four (1911) 3 The Recoresy (1909), a sensational "success" story 
background of each ${ }^{1}$, but the only vital parts of these stories are the accounts of hunting and trapping in the Rocky Mountains and of the conflicts between the heroes and hostile Indlans.

In 1912 and 1913, he published the three books of The Texan Serieg. These stories are built around the historical facts concerning the Texan struggle for freedom and they make the youthful hero a participant in the exploits of liartin Palmer, Erasmus smith, Henry Karnes, and Davy Crockett.

In 1913, he wrote another story of the Southwest called Apache Gold. It tells of a young hero's successful search among the high mountains of the southwest for a treasure lost by spaniards many generations earlier. It gives an account of the hero's struggle with the Apache Indians who are also in search of the

1

The Last of the Chiefs is a story of the sloux War $(1874-76)$ and ends when General Custer defeats these Indians and causes the last of thelr chlefs to rotreat into Canada. The Horsemen of the Plaing 18 a story of the war with the Cheyenne Indiang in 1866. The Quest of the Four is a story of the Mexican War. 
lost treasure.

Between 1914 and 1916, he wrote a story of the Civil War in eight rolumes. ${ }^{2}$ Mrs. Altsheler atates that these books were written in response to a request from his publishers for "a series of books on the civil War, four on each alde of the question". Those parts of the story which probably grew out of the tales of the civil War told to the author during his boyhood are interestingly and convincingly told. He wites convineingly of Iife in small towns in Kentucky and of the dramatic scenes taking place in Charleston, south Carolina in 1865. His characterlzation of stonewall Jackson and Robert $\mathrm{E}$. Lee reflects the influence of the author's contacts with Civil War veterans who had known these men personaliy. His accounts of the suffering endured by the men of the southern axmies during the last fer months of the was are rery realistic and had probably been told to him by southern reterans.

IThe Guns of Bull Run (1914), The Guns of Dhilon (1914), The Scouts of Stonewail (1914) the Sword of Antietam (1914), the Star of Gettroburs (1915), The Rock of Chiclogmaurua (1915), The ghades of the Wilderness (1916). The Iree of Appomattox (1916) 
During the year 1915, he wrote three stories ${ }^{2}$ recounting the adventures of an American youth who was traveling in Germany when the World War began and who fought on the side of the French during the first year of the war. In the foreword to the flrst of these stories, Nr. Altsheler writes:

It was the singular fortune of the author to be present at the beginning of this, the most gi eantic struggle in the history of the globe. He was in Vienna the day AustriaHungary declared war upon servia, thus setting the torch that Ilghted the general conflagration. Returning westward, he reached Munfch the day Germany declared war upon Russia. He remained in Gexmany nearly a month, having witnessed in turn the Austrian and German mobilizations, and arrived in Encland in time to see the gathering of the British Propire's armed hosts. Such an experience makes an ineffaceable impression and the author has atriven to

1

The Guns of Europe (1915)

The Forest of Sworde (1915)

The Hosto of the A1s (1925) 
reproduce them in these romances.

These Forld War stories, however, are the least popular of his serials.

In 1918, the two books of The Great West Deries ${ }^{1}$ were published.

Between 1916 and 1919, he wrote a geries of six books dealing with the period of the French and Indian War. Altsheler 18 seen at his best in this series and in The Young Trailers. In both series, there are many forest scenes and the heroes are boys who love the forest as Altshelex had loved it. What seems to have been the most vital paxt of his boyhood in Kentucky gave life and vigor to hig story-telling at its best.

Ipe Great Sioux Trail (1918), The Lost Hunters (1918) 


\section{Part Two}

An Analysis of Altsheler's Fiction for Boys 


\section{Chapter One}

Altoheler's Formula for Characterization

in

Boys' Fiction 
Chapter One

Altsheler'g Formula for Characterization in

Boys' Fiction

Part one of this thesis has outlined the development of American fiction for boys, has discussed the baokground and personality of Joseph A. AtIshelex, and has given a brief review of his writing. Since his stories for boys constitute his most worth-while contribution, they will be discuesed in Part Two.

An examination of these stories shows that Altsheler, like mogt writers of boys' fiction, followed a pattern or formula for characterization and storytelling. This chapter will discuss his formula for characterization with its variations. In the characterization, seven points axe evident.

First, each story uses a large number of background figures. In order to introduce historical incidents and to give the readex a sense of large events in the American scene, these are necessary. Second, each story uses a comparatively small number of foreground figures. This is because Alt-sheler was writing for immature readers who demand a 
swiftly moving story with few central characters.

Third, the characters are predominantly male. This is to be expected, since most of Altsheler's stories were written for boys. In all of his novels for boys there are only about twenty women or girls who play parts of any importance and only ten of these are foreground figures.

Fourth, the organization of foreground characters is the same in most stories. The hero is the central flgure and around him are grouped from one to six companions and an antagonist.

Iffth, the background figures are organized around the hero in three groups. In the first group are his family and friends. In the second are the historloal charaoters with whom he 1 s associated. In the third are types which are characteristic of the American scene of the period.

Sixth, each of these groups of background figures performs a definite function in the stories. In the books which introduce scenes from settlement life, the family and friends of the hero help to create the picture of the frontier settlement and give opportunities for the demonstration of specific character traits of the hero. In all of the stories, historical and type 
characters help the author to reproduce historical background and incident and to reveal the characters of his heroes.

Seventh, the foreground figures conform to the following patterng.

The hero is the type of American youth whom Altsheler considers worthy of being emulated by his jurenile readers. Fundamentaliy he is a combination of a woodsman and a school boy, a product of the combined influences of the settlement and the forest. He is adventurous and resourceful, yet intelligent and imsinative. He possesses a strong will, yet he is adaptable and courteous. He does not underestimate dangers and difficulties, yet he is an optimist. He is capable of accomplishing seemingly impossible tasks, yet he is always modest. He is courageous, yet generous in his treatment of friend and foe. He is loyal to friends, country, and beliefs, yet he is free from religious and race prejudices. He is a trustworthy friend, a fine soldier, and a splendid leader. He is willing to face danger and endure hardships in order to give help to those who need it. He is a veritable knight of the forest. 
In the group of companions, there is always one character whose function is to give the hero an opportunity to display his generosity, tact, kindness, and leadership as well as his physical strength and endurance. This charactex is a boy who plays the part of a younger brother. He is a friend who is about two years younger than the central figure and who is superior to him as a student and thinker but is his inferior as a woodsman. He is sometimes introduced as a boy who is physically unable to perform his share of the duties of camp and trail but who develops physical strength and hardihood as a result of his life in the wilderness.

The function of a second member of this group of companions is to allow the reader to see the hero as an intelligent pupil who learns readily and thoroughly his lessons as hunter, trailer, and woodsman. This character is an older man who stands in the place of a father to the hero and whose superior wisdom helps the boy to develop into an expert woodsman.

The refinement of the hero is emphasized by the introduction of a third companion who is a typical backwoodsman entirely lacking in education and culture. A second function of this character is to give the 
hero a chance to demonstrate his democratic spirit by bringing him into his clrcle of close friends and companions.

The superiority of the hero is sometimes further emphasized by the introduotion of another companion who becomes the self-appointed cook for the group, thus relleving the hero and his friends of mental tasks.

The character of the hero is brought into bold relief by means of contrast with an antagonist who is his antithesis in many ways. The hero is generous. His antagonist is selfish and greedy. The hero is frank and sincere. His antagonlst is dishonest and treacherous. The hero is unfailing in courtesy. His antagonist is impolite and rude. The hero's successes are the result of courage and intelligence. Those of his antagonist result from cunning and treachery. The hero wins the respect and admiration of friend and foe. His antagonlst is despised even by his allies. The final triumph of the hero over the antagonist is always the triumph of a trained mind over an untrained one, of sincerity over treachery, and of a loyal splrit orer a disloyal one. These seren points of the Altsheler formula are 
best 11lustrated by the Young Trailer Series. ${ }^{1}$ First, this serles uges fifty-eight background figures. Second, it uses only six characters in the foreground. Third, there are only four female figures and only one of these plays an important part in the story. Jourth, the foreground figures are the hero, four companions, and an antagonist. Flfth, the background figures fall into three groupe, namely, the friends and relatives of the hero, the historical characters with whom he $1 \mathrm{~s}$ associated, and type characters of the Revolutionary War period, sixth, the background figures help to reproduce the American scene of the Revolutionary Wax period and to reveal the character of the hero. Serenth, the foreground figures conform to the definite pattern already mentioned. An analysis of the $s i x$ central characters will show how they conform to the formula. The hero, Henry

1

This series includes: The Young Trailers (1907) The Foreat Runners (1908), The Keepers of the Tra11 (1916), The the of the Woods (1917), The ree Rangers $(1909)$, The Riflemen of the Ohio (1910) The Scouts of the Val1ey (1911), The Border Watch(1912). The series originaliy contained only six books. The books published in 1916 and 1917 were written in compliance with requests for additional stories about The Youns Trallers heroes and were placed third and fourth in the series as indicated in the above list. 
Ware, is a boy of a backwoods Kentucly settlement called Wareville. When about twelve years of age, he has come with his family from Maryland. He has attended school in Maxyland and he attends the backwoods school in the Wareville settlement. But, whlle still a mere boy, he becomes such a skillful hunter and trailer that the men of the settlement allow him to accompany them on huntIng and exploring trips. While on one of these trips, he allows himself to be captured by Indlans rather than betray his father and friends. His love of adventure, his courage, his tact, and his skill as a hunter win the respect of his captors who soon begin to treat him as a friend rather than as a captive. When he learns that the Indians are planning an attack upon Fareville, he makes his escape and reaches the settlement in time to give the waxning and help to repulse the attack. He later becomes the greatest forester of the border, a forest runner who warns frontier settlements of threatened attacks, saves emigrant trains from Indian ambush, and thwarts the best-laid plans of redskin and renegade. He is a knight of the forest and a typical Altsheler hero.

The companions of the hero are: Paul cotter, who plays the role of the younger brother; Tom Ross, the 
"fatherly" friend; Solomon Hyde, a daring and resourceful backwoodsman, "a child of nature"; and Jim Hart, an expert woodsman and a prideful cook.

Paul Cotter, friend and companion of Henry Ware, is about two years younger than the hero. While they are yet boys living in the backwoods settlement, Paul 1s more of a student than a forester. He goes on hunting trips with Henry, but he does not possess Henxy's unusual size, strength, and skill, nor does he share hid distaste for settlement life. By the time the fotends are sent on their first long wilderness joumey, Henry has already become a great hunter and trailer and Paul readily acknowledges his superior skil1. During this journey, as on many later ones, Henry is the leader and Paul the follower. Paul loses his way in the forest, is captured by a band of Indians, and is rescued by Henry. Thus, Henry is given an opportunity to show that he is a superior woodsman, a kindly friend, and a real leader. However, as a result of long experience in wildemess $11 \mathrm{fe}$, Paul develops into a good woodsman, though he is always inferior to Henry Ware.

The "fatherly friend" of Henry Ware, Tom Ross, is a typical backwoodsman who is Henry'g inferior in 
native intelligence as well as in refinement. But he is a skilled hunter and trailer who becomes Henry's teacher in woodscraft and who furnishes the opportunity for the hero to demonstrate his superior ability as a learnex.

Solomon Hyde is the "ohild of nature" who is one of the hero's closest companions. As a soout, hunter, and trailex, he is second only to Henxy Ware; but he is entirely lacking in education and refinement. He serves the double purpose of acting as a foll for the more refined Henry and Paul and of providing an opportunity for them to display their democratic spirit by making him a member of their band of foresters.

The antagonist of the hero, Braxton Wyatt, is a boy who grows up with Henry Ware and Paul Cotter in the Wareville settlement. Inferior to Henry as a hunter and trailer as well as in abllity to win friends in the settlement, he becomes a jealous enemy. He is clever, but treacherous and selfiah. Unable to win popularity or prestige in the settlement, he allies himself with the Indians. Thereafter, much of the action of the stoxy is motivated by the conflict between Braxton Wyatt, the renegade foe of his race, and the knight of the forest, Henry Ware. Henry Ware's 
triumphs over Wyatt come as results of superior intellect, superior training, the intervention of friends, and Divine guidance and help.

An analysis of the background figures in this series reveals their function in the story. The fami$1 y$ and friends of Henry Ware create the picture of settlement 1 ife and also furnish opportunities for the hero to give warnings of threatened Indian attacks, to ald in driving off the Indians when they do attack, and to provide food for his family and friends during a cold winter when game is scarce. The group of historical characters which includes Daniel Boone, Simon Kenton, George Rogers Clark, Benfamin Logan, James Harrod, and simon Girty is an important part of the Kentucky scene of the period. These characters also furnish opportunities for many of the knightly deeds of the hero and his companions. The function of the British officers and their allied Indian chiefs who are introduced as type figures is to give a sense of the effect of the Revolutionary War upon the frontier settlements. This fundamental formula for characterization obtains, with variations, in all of the other series. The Texan Serieg, ${ }^{1}$ which comes closegt to the formula

This series includes: The Texan Star (1912), The Texan Scoutg (1912), The Texan Triumph (1913) 
uses forty-two characters of which five are foreground figures. All of the characters are male and the foreground figures include the hero, an older friend who is his teacher in woodscraft, a companion who is a rough and uncouth frontiersman, and a treacherous antagonist. Bdward Fulton, the hero, 1s described as "a young student, his head filled with the completed drama of the past and able to see into the future of his country, brave, resourceful, loyal, intelligent." William Allen, the younger companion, Obed White, the "fatherly" friend, and the rough frontiersman, Martin Palmer, perform functions similax to those of Paul Cotter, Tom Ross, and solomon Hyde in The Young Trailers. The antagonist is a Mexican spy. Settlement Ife has no part in this story, so the famlly and friends of the hero are not used as background figures. Historical characters give vividness to the western picture and motivate much of the action of the hero. Among these are Stephen Austin, Sam Houston, Davy Crockett, Ben Milam, Santa Anna, and General Cos. John Roylston, a financier and Texan patriot, is an interesting type figure. Another is the Rev. Stephen Larkin, a frontier preacher who takes part in the fights with the Mexicans. 
Next to The Texan Series, the formula for characterization is most evident in The Civil War Series. ' Many of the features of the formula are found in the French and Indian War series, 'The Great West Beries, 3 and The World War Serieg, 'but these three series also present many variations. The non-serial stories in which the formula is most evident are Apaohe Gold ${ }^{5}$ and The last of the Chiefs."

The formula for characterization is more evident

1

This series includes: The Guns of Bull Run (1914), The Guns of shiloh (1917), The scouts of Stonevali (1914). The Srord of Ant letam (I914), The Stas of Gettyaburg (1915), The Rock of Chiokamaurua (1915), The chades of the Wilderness $(1916)$, The Tree of Appomattox (1916)

2This series includes: The Hunterg of the Hills (1915), The Shadow of the North (1917). The Rulers of the Lakes (1917) Theters of the Peaks (1918), The Iords of the W11d (1919), the sun of Quebec (1919)

Th1s series includes: The Lost Hunters (1918) The Great sioux Tra1l.

This series includes: The Guns of Europe (1915). The Forest of Swords, (1915), The Hosts of the Als (1915)

51913

${ }^{6} 1908$ 
in the serial ${ }^{2}$ stories than in the non-serial ${ }^{2}$, but variations in character distribution and character patterns are found in both types of story.

Variations in character selection and distribution occur in the non-serials. The Iast of the Chiefs uses two boys as heroes. The Horsemen of the Plains uses only one, The Quest of the Four uses four strong characters as central figures, while Apache Gold. I1ke many of the serials, uses a hero, a pal of the hero, an oldex man who plays the part of fathex to the hero, and another man who performs the menial tasks of the camp.

Variations in character selection and distribution also occur in the serial stories. The French and Indian War Series uses three antagonists. One of these is the antagonist of the hero and the other two are opposed to the two companions of the hero.

1

Of Altoheler's thirty four books for hoys, thirty belong to one of the series. The berials are: The Young Prailers (8 books), the Civil War Serieg $(8$ books $)$. The Texan Series $(3$ books). The Great West Series (2 books). The World Was Series (3 books). The French and Indian War series (6 books)

2

The non-serials for boys are: The last of the Chiefs (1909), The Horsemen of the Pla ins (1910), The Quest of the Four (1911), and Apache Gold (1913) 
All three are foreground figures. Another foreground figure which is added to this series is a French nobleman who is connected with a mstery surrounding the ancestry of the hero. Four books of The civil War Serles are written from the Northern point of view and four from the southern. Hence there are, in this series, two distinct groups of characters. Hach group includes a hero, an antagonlst, and historical and type characters. The two boys used as heroes are natives of the same Kentucky town and their friends and relatives in this town are used as background figures throughout the series. In The World War Series, a French girl is uged as one of the foreground characters.

Varlations in character patterns occur in serials and non-serials. An interesting one occurs in the non-serial, The Horsemen of the Plains. The hero of this story is not a knight of the plains bent upon the performance of knightly deeds, but merely a brave youth seeking adventure for its own sake.

Wore interesting variations in character patterns are found in the serial stories. The hero of The French and Indian Wax Series is, like other Altsheler heroes, an adventurous youth who loves the forest and 
becomes a skilled woodsman, trailer, and soldier. But the author has emphasized his lofty imagination, his gift of diplomacy, his graceful and fluent speech, and his sensitiveness to impressions. Thus, he has transferred to the hero some of the outstanding qualities of Paul Cotter, the "younger brother" companion of Henry Ware in The Young Trailex Series. At the same time, he has given to Tayoga, friend and companion of Robert Lennox, some of the sterner qualities of Henry Ware. Tayoga is a young Iroquois chief who is much more skillful than Robert Iennox as a hunter and trallex. He becomes the teacher and guide, and the hero becomes the leamer. Thus the big brother and the younger brother exchange places. In this series, David Willet, who stands in the place of a father to the hero, is a much more dominant character than any other "fatherly friend" in the Altsheler stories. He is much more than an ordinary woodsman. He is an 1 educated and cultured Inglishman who has lived in Paris as well as in London. From him the hero learno tact and diplomacy as well as woodscraft. By him he is taught swordsmanghlp as well as skill with rifle

The Hunters of the Hi118, pp. 77, 114, 176, 180,181, 201 
and arrow. As a result of this teaching, the hero finds himself equally at home in the great northern woods and in the French soclety of quebec. Both Tayoga and David Willet are dominant figures and their importance in the series is emphasized by the use of Adrian Van Zoon and Tandakora as their antagonists. The characters of these two antagoniats are fundamentally the same as that of Achille Garay, the antagonlst of the hero.

In The Texan Serieg, the "fatherly friend", Obed White, is also a "child of nature" like solomon Hyde in The Young Trailerg.

It has been mentioned that two heroes are used in The Civil War Serieg. These boys, Harry Kenton and Dick liason, are cousins who live in the little village of Pendleton, Kentucky. Harry Kenton is the great-grandson of Henry Ware and Dick Nason is the great-grandson of Paul Cotter. Each has inherited the character traits of his great ancestor. In the treatment of their boyhood in Pendleton, Kentucky, there is a suggestion of the Henry Ware-Paul Cotter relationship between them. They enter the war to fight on opposite sides and each becomes the central figure in a lurge group of characters. Thus, The Civil War series, has two heroes, the character pattern 
of one being like that of Henry ware and the other like that of Paul Cotter. The antagonists in this series are admirable characters capable of showing personal friendship toward their official foes.

In The World War Serleg, the closest friend of the hero is the "big brother." He is France's greatest aviator and becomes the champion, guide, and protector of his American friend who is the hero of the series.

Iren with these variations and numerous other less striking ones, the characterization in all of the Altsheler stories is very similar. However, this similarity is not objectionable to juvenile readers, since they are interested in following the adventures of heroes whose characters are altogether attractive and who triumph over antagonists who are obviously villainous. 


\section{Chapter Two}

Altsheler's Formula for Story Movement 
Altsheler's Formula for Story Movernent

There is a definite relationship between Altsheler's formula for characterization and his formula for story. movement. Since his heroes are knights of the frontier and battle field, his stories center around the knightly deeds that they do. The performance of these deeds always centers around similar incidents. Hence, the outlines of the story movement are very much alike and may be expressed in the following formula:

First, each hero attempts a succession of difficult tasks which are undertaken in the interest of principles in which he believes or in behalf of persons in need of help. The usual tasks are carrying messages and warnings.

Second, the attempts to carry out these commissions call for the exercise of unusual intelligence, skill, strength and endurance and lead to action which includes

(1) participation in battle

(2) flight from pursuing foes

(3) capture

(4) long periods of captivity

(5) escape 
Third, escape from pursuing foes or from captivity sometimes results from the bravery and skill of the heroes, sometimes from the intervention of friends, and sometimes from Divine ald.

Fourth, the incidents accompanying the accomplishment of the tasks reveal the character of the heroes and their companions and of their antagonists and enemies.

Fifth, the heroes always succeed in accomplishing the attempted tasks.

The best illustrations of this story-telling formula are found in the first, third, fourth, and fifth books of The Irench and Indian Wax Serieg. The heroes of these stories accomplish definite tasks which aid the English in gaining supremacy on the American continent.

The Hunters of the Hills, the first book of the series, is the story of the accomplishment of two such tasks. It naturally divides itself into two sections both of which contain elements of the formula for story movement.

The first task attempted by the heroes, Robert Iennox, Dave Willet, and Tayoga, is to carry important letters from the English Governor of New York to the French Governor General of Canada. This necessitates a journey through the wilderness from Albany to Quebec 
in the year 1755 when both French and Indians are asserting their claims to the northern woods. The journey becomes a continuous flight from purguing Indians. The pursued are saved from captivity and death three times by their own skill and bravery, once by a atorm on the lake, twice by the help of friends, and twice by mere chance. Because of superior intelligence, bravery. and diplomat1c skill, they overcome treacherous foes in Quebec and succeed in delivering their letters.

The incidents of the journey and the experiences in Quebec are dramatically told. There is a series of peaks of interest which build toward the climactic scene in Quebec which brings about the accomplishment of the mission of the hero. Much use is made of such devices as contrast and suspense and the story moves forward without too much attention to detail.

The second task is to influence the Iroquois leaders to refuse to make an alliance with the French. This makes it necessary for the three to travel through the wilderness from Quebec to the Onondaga Valley in New York and for Robert Iennox to address the Iroquois Counc11. In telling the story of the joumey, the flightpursuit element of the pattern is used. The heroes are pursued by Indians. Once they make their escape 
because of their own skill and aaring, once because of a storm, and once because of a meeting with a party of friendly Indians. They reach their destination in safety and, at the Council of the Six Nations, Robert Lennox enters the contest with the splendid orator whom France has sent as her ambassador. There, his unusual intelligence and graceful and dramatic speech cause the English to decide against the alliance with the French.

Altshelex writes of the meeting of the Council in the Northern forests in such a way as to allow his characters to express his own love of the woods. However, his long description of the Indian ceremonles becomes tiresome and slows up the movement of the story. The Rulers of the Lakes, the third book of the series, falls into four sections each of which is concerned with a self-appointed task accomplished by the heroes, Lennox, Willet, and Tayoga.

The first task is to carry the news of General Braddock's defeat to the defenders of a remote English fortress. The story of the journey is the story of flight and escape from pursuing Indians.

The first task successfully accomplished, the knights of the forest find the second in conductine 
the retreat from the fortress to the settlements near Albany. They organize a band of brave foresters which acts as a curtain between pursuing Indians and the women and children in the wagon train. The journey is attended by: one day of safe travel; an attack by three hundred warriors; a combat in which a clever trick of Tayoga's. saves the wagon train; the withdraw of the pursuers; and the arrival of a band of friendly Indians who pursue the retreating foe. The emphasis upon the helplessness of the pursued makes the reader feel the importance of the service which the heroes can give and enables him to identify himself with them as they give it.

When the fugitives thus saved from attack scatter amone their relatives in the settlement, the third task is undertaken by the heroes. This time, they join a band of one hundred foresters who attempt to strike a blow at the French on lake George. The incidents of the journey to Lake George include pursuit and combat and the result of the undertaking is the capture of a large part of the French fleet. This part of the story is not so convincing as the account of the preceding task. His battles are not based on experience. Learning that the French are about to attack 
Albany, the heroes aturt immediately on a return jousney in order to carry a warning to General Johnson. This fourth task is accomplished after a journey attended by flight, pursuit, and combat.

The Masters of the Peaks, the fourth book of this series, is the story of a bold attempt of Lennox, Willet, and Tayoga to bring to the English generals information about the plans of the French. The first part of the book is concerned with the attempt to gain the informetion and the second part with the attempt to carry it to the Inglish and Amerlcan leaders. The first task takes the heroes through the northern forests among the mountains near Canada and the second takes them over another maze of mountains to lake George. The attempt to gain the desired information leads to desperate struggles against cold and starvation, flight from pursuing foes, combat, and the ultimate capture of a French spy from whom valuable letters are obtained. The story of the battle with cold and starvation is very realistic. The attempt to deliver the letters to Colonel Johnson brings about the separation of the heroes. It causes Robert Lennox and Tayoga to spend part of a fierce northern winter among the bear caves in the northern mountains. It brings about the capture of 
Robert Lennox by a party of French scouts, a long period of captivity for him, ultimate rescue by Tayoga, and the delivery of the letters by Willet. The trials of the wintex reveal the great powers of endurance, skill as hunters and trappers, and the unusual optimism of Robert Lennox and Tayoga. The incidents of the lone captivity of Robert Iennox reveal his courtesy, tact, bravery, and fair-mindedness, and his loyalty to the English. They also reveal the same fine qualities in Montcalm and the other French leaders. Tayoga's rescue of Lennox reveals his patience, loyalty, intelligence, skill, and daring and is one of the most dramatic scenes in the story.

The story of The Lords of the Wild, the fifth book of the series, hinges upon the attempt of Lennox, Willet, and Tayoga to accomplish aix successive tasks. These tasks are concerned with the rescue of captured friends, obtaining information about the plans of the enemy, carrying warnings to friends who are about to be attacked, and aiding in the defense of towns and forts. The attempt to accomplish them brings about flight, pursuit, intervention of friends, participation in a great battle, and rescue from danger through Divine aid. 
This fundamental formula for story movement obtains in all of the serial stories. It is very evident in The Youns Trailex series, where the stories are based upon the knightly deeds of Henry Ware, Paul Cotter, Tom Ross, sol Hyde, and Jim Hart. The tasks which they perform aid in the establishment and maintenance of American settlements west of the Alleghenies. These knights of the frontier give warnings of threatened Indian attacks, help to save besieged towns, give the settlers information concerning the plans of the Indians, carry supplies of gunpowder to remote settlements, save emigrant trains from annihilation by ambushed Indians, and frustrate carefully laid plans of British generals and allied chiefs. These tasks call for intell1gence, a thorough knowledge of the forest, bravery, ski11, patience, and an understanding of the Indians. In attempting to accomplish them, the heroes participate in battle, are pursued by Indians, are often captured, sometimes spend long periods of time in captivity, and are rescued by friends or through Divine aid. The following paragraphs from the chapter called The Battle in the Forest illustrate Altsheler's method of motivating the story movement in The Young Trailers:

The plan must be frustrated at once, and Henry 
Ware never hesitated. He must bring on the battle, before his own people were surrounded, and raising his rifle he fired with deadly aim at one of the chiefs who fell on the grass. Then the youth raised the wild and thrilling cry, which he had learned from the savages themselves, and sped back toward the white force. ${ }^{1}$

The following paragraph shows how Altsheler makes use of the suspense device in relating the experiences of his heroes when their attempt to aid their families and friends result in attacks by the Indians.

The stillness was now so deep that even the scouts could hear no sound in front. The savage axmy seemed to have melted away, into the air itself, and for full five minutes they lay, waiting, waiting, always waiting for something that they knew would come. Then rose the fierce quavering war cry poured from hundreds of throats, and the savege horde, springing out of the forests and thickets, rushed upon them.

1

The Youne Trailers, p. 289

2Ibid., p. 292 
The stories told in The Texan Series center around the exploits of the hero, Edward Fulton, and his companions. The deeds of these young men aid the Texans in their struggle for freedom from Hexico. Their tasks are: to discover the plans of the Mexicans, to carry warnings to the Texans, and to bring help to besieged towns and armies. Incidental to the carrying out of these tasks are attack, flight, pursuit, capture, imprisonment, escape, and participation in many battles. The stoxy-movement formula is evident in all of the stories of the Ciril Wax Serieg. D1ck Miason, who Is the hero of The Gung of shiloh, The sword of Antietam, The Rock of Chickamaugua, and The Tree of Appomattox, is a young man to whom important and dangerous commissions are assigned by the generals under whom he serves. His assigned tasks are: to carry messages from one general to another, to penetrate tnto the southern lines in order to gain valuable information, to give warnings of the approach of the enem, and to obtain aid for generals who are being attacked by overwhelmingly large numbers. Harry Kenton, the hero of The Gung of Buld Run, The Scouts of stonewal1, The Star of Gettysburse and The Shades of the Wilderness, performs similar tasks for the southem generals. In carrying out their commissions, 
these young men alternate flight and pursuit with short periods of rest and with participation in desperate battles. They accomplish tasks which seem impossible and their capture by their enemies is prevented by their own cleverness and daring, by the help of friends, or by Divine aid.

The Great West Series tells the story of a boy's attempt to accomplish a task which has been assigned to him by his father. It necessitates a journey into the land of the hostile sioux. It brings about flight, pursuit, capture, a long period of captivity, and ultimate rescue by friends. The happenings of the story reveal the characters of the hero and his long captivity serves to reveal the character, superstitions, beliefg, and mode of life of the sioux Indians. In the Lost Hunters, the second book of the series, the story of the hero's experiences as a captive and adopted son of a sioux chief is very interestingly told. This is one of Altsheler's most convincing stories and gives the reader the impression that the author must have spent some time among the Sioux tribes. However, Mrs. Altsheler states that, while the information about the Sloux Indians is authentio, it is the result of much research and not of first-hand experience. 
The story told in the three books of The World War Serieg fall naturally into two parts. The first part hinges upon the exploits of Philip Lannes, a French aviator whose duties are similer to those of Harry Kenton and Dick Mason of the Civil War series. His tasks are undertaken in the service of France. He makes dangerous journeys in order to discover the plans of the Germans, he carries important messages for the French generals, and he cleverly thwarts the plans of his foes. The performance of his tasks involves flight, pursuit, attack by enemies, participation in battles, capture, imprisonment, and escape. The story of his deeds reveals his extreme loyalty to his country, his daring, his skill as an aviator, and his native courtesy and kindness.

The second part of The World War Serles is concerned with a self-appointed task of John Scott, the Arnerican hero. The task is the rescue of Wademoiselle Julie Lannes, beautiful sister of Philip Lannes who has been captured by an Austrian officer. The succession of events which lie between the undertaking of the quest and its accomplishment includes flight, pursuit, escape, the aid of Divine providence, and the employment of unusual daring and skill. It also revedis the 
characters of all of the foreground figures in the story.

Among the non-serial stories, the story-movement formula is most evident in The quest of the Four. This is the story of the Mexican War, and the central character is Phil Bedford, a young man of Paris, Kentucky. The task undertaken by $\mathrm{him}$ is to find and rescue his brother who has been imprisoned in Hexico. In trying to accomplish it, he and his companions are pursued and attacked by Comanche Indians. They escape, join General Taylor's army, and take part in battles in the Pass of Angustura and at Buena Viata. The intervention of friends and Divine aid play a large part in the ultimate rescue of the brother.

The Quest of the Foux conforms more closely to the story-movement formula than do the other non-serials. Yet, it presents one important variation. In the serial stories, the heroes and their companions unite in the performance of tasks in which all are interested. In The quest of the Four, each of the four young men is bent upon a quest of his own. Brought together by chance, the four companions unite in the performance of the four tasks. 
Decided variations from the story-movement formula occur in The Horsemen of the Plains. The hero is not engaged in the performance of a succession of knightly tasks. He joins a band of fur trappers and goes with them into the Rocky Mountains solely because of his desire for adventure and the tale of his experiences in hunting and trapping does not follow the outline of the story-telling formula. Yet, even in this story, elements of the formula are found in the story of two encountexs with the Cheyenne Indians. After leaving Omaha, Robert Norton and his companions are attacked by a band of warriors. They escape, are pursued, engage in battle, and are saved "by the providential intervention of an immense buffalo herd." The second encounter takes place when they leave the mountains and prepare to cross the plains in order to take their furs to the Eastern market. They are attacked and Robert Norton is captured and taken to a Cheyenne village. He escapes, is saved from death on the plains by Colonel Forsyth of the United States army, and participates in two great battles with the Indians before he is able to rejoin his friends.

The same type of variation is found in the storymovement in Apache Gold. The exrand that takes Charles 
Wayne, the hero, into the mountains of the southwest is not a knightly one. He goes in search of hidden spanish treasure and not in behalf of those who need his aid, but the pattern of the story of his adventures does not differ from that of most Altsheler stories.

In The French and Indian War Series, an important variation from the story-movement formula is the introduction of an element of mystery concerning the parentage of the hero, Robert Lennox. Facts connected with this mystery supply the reason for the fatherly attitude of Dave Willet toward Lennox, for Willet's having come to America, for Robert's having spent so much time in the wilderness with Willet, and for his having so many powerful friends in New York, in Albany, and in the French army. The element of mystery is also responsible for a variation in the character formula, bringing into the story the charming Frenchman, Le Chevalier de st. Luc, and the antagonist of Dave Willet, Adrian Van Zoon. No other Altsheler story uses more than one antagonist and no other introduces a character corresponding to st. Luc. Wuch of the action of the story centers around these two foreground figures and it is through them that the character of the hero is revealed and interpreted. The sun of quebec, the last of the series, is 
concerned almost wholly with this mystery which provides the opportunity for the introduction of a sea fight, a storm at sea, shipwreck, and a scene on an island of the West Indies. It also gives the author the opportunity to place the hero in a new and trying situation where his courage, resourcefulness, optimism, faith, and strength of will are revealed.

Much of the first book of The Young Trailer Series is concerned with historical background and incident instead of the performance of knightly deeds. It is the story of the childhood of Henry Ware, the hero, and the reader watches $h$ is development, under the combined influence of forest and settlement, into a knight of the frontier.

The Iost Funters, the second book of The Great West Series, is a description of life among the Sioux Indians. The captivity of Will Clarke, the hero of the series, and his adoption into the tribe furnish the opportunity for this departure from the story formula. Nost juvenile readers do not object to the similarities in the pattern of the Altsheler stories. This is partly due to the varlety of historical and geographical settings. The authentic and accurate representation of the fimerican scene was one of Altsheler's purposes, 
and his method of carrying out this purpose will be discusged in the next chapter. 


\section{Chaptex Three}

Alshelex's Treatment of the American Bcene 


\section{Altsheler's I'reatment of the American Scene}

Altsheler presents the American scene of 1755-1890 by giving a picture of eight distinct historical periods, namely, the periods of the French and Indian War, the Revolutionary War, the westward expension at the end of the eighteenth century, the War of 1812, the Texan Revolution, the War with Mexico, the C17il War, and the westward expansion between 1866 and 1890. To get a pioture of the American scene as Atlsheler presents 1t, It is necessary to examine three of the books which were intended for adults but which have been taken over 1 by boys.

H1s method of presenting the scene at each of these periods grows out of his characterization and his storytelling. His heroes are patriotic young men who serve their country by carrying important messages for its leaders, by defending 1 ts frontier settlements, and by fighting in its wars. His stories are concerned with their adventures, and the American scene unfolds as their duties take them into the wilderness and into the towns and settlements. He presents each part of this unfolding scene by giving an impression of the every-day

IA soldier of Manhattan. The Wilderness Road, A Herald of the West 
1ife, by creating characters which are typical of the time and place, by introducine historical characters, by describing important historical events, and by allowing spokesman characters to discuss political and social situations and problems.

An analysis of his treatment of the scene of the French and Indian War Period will illustrate his method. This period is presented in the six books of The French and Indian War series.

The elements of the Amexican scene represented in these books are the wilderness extending north and west of the settlements, the cities of Kontreal, Quebec, Albany, New York, Williamsburg, and Boston, and the French and English forts along the northern lakes and at the junction of the Allegheney and Monongahela Rivers.

None of the action of the stories takes place in Philadelphia, but there is a consclousness of this town as a place where people are "counting their gains in the West India trade, looking at the latest fashions from Ingland, building houses out Germantown way, and none thinking much about the war except old Ben Franklin." ${ }^{2}$ Of all of these elements of the scene, the one which is made most prominent is the wildemess of the

${ }^{1}$ The Shadow of the North, p. 89 
northern and western frontier. Altsheler presents it as the scene of the adventures of his heroes. who make long journeys into "the great northern wilderness extending from the Hudson to the Ohio and from the st. Lawrence to the Tennessee." ${ }^{2}$ He describes this region as one of great beauty, of splendid trees and blue lakes and high mountains. By relating day-by-day experiences of his heroes, he shows that it is the soene of constant warfare between the English, ${ }^{2}$ the French, ${ }^{3}$ the Hurons, 4 and the Iroquois. 5 Because the heroes are messengers of the English Governor of New York, they become a part of this warlike scene. They are repeatediy attacked by Western and Canadian Indians who are allied with the French. They are attacked by Huron warriors and are saved from capture by bands of Mohawks who are allied with the Iroquols. They foin forces with the Pennoylvania militia in bullding and holdine a fortress designed to protect Inglish settlements along the frontier. They are pursued, attacked, and once captured by French scouts.

The Hunters of the Hills, p. 5 $2-3-4-5$ Ibid., p. 28 
The northern wilcierness is also presented as the land of the Hodenosaunee or Six Nations. ${ }^{1}$ The emphasio placed upon the efforts of French and English to secure an alliance with these Indians gives the reader a sense of their numbers and of their power in the northesat. The efforts of these rival powers are brought to a cli$\max$ when their ambassadors make their appeal to the fifty sachems at their annual council meeting in the vale of Onondaga in northeastern New York. The description of this council brings before the reader the "intertwined religious, military, and political systems of the Hodenosauseen ${ }^{2}$ with its council of Thanksgiving, 3 its ceremony of the confession of sins and repentance, its festival of the Maple Dance, 5 and its political council of the fifty sachems. 6

Altsheler gives a sense of reality to this scene by making some of the historical characters very vivid.

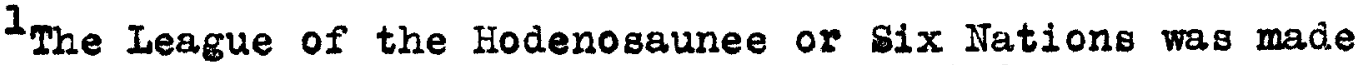
up of Onondagas, Mohawks, Cayugas, Onledas, Senecas, and Tuscaroras

2 The Hunters of the Hil1s, p. 336

3

Ibid., p. 337

4 Ibid.,pp. 341, 342

5 Ibid., pp. 342, 343, 345

6rbid., pp. 352, 360 
The most outstanding ones are: Captain Jack, or Black Rifle; ${ }^{l}$ Robert Rogers and his band of rangers; and Colonel William Johnson with his Indian wife, Molly Brant, and his brother-in-law, Joseph Brant.

He also introduces characters that are typical of the time and place and some of them are very life-like. Among these is Zebedee crane. While he is an historical character, he is also an example of the typical backwoodsman who fits naturally into the forest scene but is out of harmony with the life of the towns and settlements. He is used in The French and Indian War Series and in $A$ Soldier of Wanhattan and, in both stories, he presents an interesting contrast to the heroes who are at ease in any environment. On the other hand, James Colden, William Wilton, and Hugh Carson, young officers of the Philadelphia militia, are typical men of the city who are unfamiliar with the forest and with Indian methods of fighting.

I Wo along the frontiex had not heard of Captain Jack, known aloo as the Black Hunter, the Black Rifle, and by many other names? The tale had been told in every cabin in the woods how, returning home, he had found his wife and children tomahawked and scalped and how he had taken a vow of lifelong vengeance upon the Indians, a vow most terribly kept. In all the viliages of the ohio country and alone the Great Lakes, the name of Black Rifle was spoken with awe and terror. No more singular and ominous figure ever crossed the page of border story. (The Shadow of the North, p. 16) 
At least two-thirds of the action of the $s i x$ books of The French and Indian War Series takes place against the background of this wilderness scene. Altsheler's problem in presenting this wilderness scene was to give it a sense of reality. He has done this by creatine the type of "admirable hero" with whom boys like to identify themselves and by making elements of the scene important factors in the success of his adventures. But some of the duties of the Altsheler heroes take them into towns and cities and these are presented in the order in which they are viaited.

Altsheler treats these parts of the American scene by means of contrast. Two French cities, one that is Dutch, one that is a mixture of English and Dutch; and two that are purely Engliah are contragted with the frontier and with each other. Wuch of the background information consisting of facts which the reader needs to know is presented by means of the conversations of the characters. Usually this is done very effectively. The French cities of the American scene of this period are Montreal and quebec. Liontreal is described as a fur-trading post which is separated from the forest by a very thin fringe of settlements along the st. Lawrence. "Hurons, Abenakis, St. Regis, Ottawas, and 
warriors from farther Weat are seen in its streets." But French troops as well as French of France and Canadian French are there, too, and the scene is peaceful. There is an excellent inn and the proprietor and the maids are typical of the scene. 2

In contrast with the fur-trading center, quebec, the seat of the French government in America, is represented as a crowded city with "a mingling of the splendid and the squalid, of French and French Canadians, of soldiers and priests and civilians and Indians, of great stone houses and wooden huts, of young officers in fine white uniform and swarthy habitants in brown homespun."3 It is described as a fortress city of stone and gray wood and many churches. In a chapter describing a ball given by the Intendant at his palace, Altshelex gives a picture of the life of the ruling class." Historical and type characters that lend life to this scerie

$\bar{I}$

The Hunters of the Hillg, p. 154

2 It's a strange world here in America. We're lying in a rocky hollow one day shooting at people who are shooting at us, and both sides shooting to kill, and two or three days later, we're sitting at an inn at a town, eating off silver and china. (David Willet in Hunters of the Hills, p. 158)

Ibid., p. 178

4he Hunters of the Hills, (Bigot's Ball, pp. 214-249) 
axe: Bigot, the Intendant; Joseph Cadet, confederate of Bigot; pean, the town mayor of quebec; the dissolute Count de Mezy; the wives of the French rulers; a dissolute bravo, Boucher; and the gallant Colonel de Galissonniere who represents the finest type of French officer.

In contrast with the French fur-trading post and the French capital, Altsheler presents the "staid Dutch town of Albany"l as a place "much like Holland where the people have preserved their national customs unto the third and fourth generations." ${ }^{2}$ Here, the reader is introduced to such typical Dutch characters as the very real and lifelike fat Dutch burgher, Mynheex Jacobus Huysman and his equally real and lifelike fat Dutch cook, Caterina.

The heroes of The Erench and Indian War Series spend much time in New York and much of the action of A Soldier of Manhattan also takes place in that town. Altsheler pictures it as a mixture of Dutch and Fnglish, "a city of red brick houses, paved streets, 3 warehouses, counting houses, and passing sailors." 4 He refers to it as not

1

The Hunterg of the Hi118, p: 175

2 Ibid., p. 175

Ibid., p. 196

Ibid., p. 202 
only a seething city commercially but socially as well," as a place where family is of extreme importance and class distinctions are preserved to the utmost possible extent. $^{2}$ In one scene at $a$ ball and in another at the theater, he makes the reader conscious of the wealth and splendor in the New York homes and of the display of jowels and fine dress at public functions.

The historical and type characters used in the New York scene give a sense of the varied life of the town at this time. The historical figure, Lieutenant Edward Charteris of the Royal Americans, with his soldier friends, helps to acquaint us with its military aspect. The sallor and visitors from foreign cities help to create the picture of a world port. Characters like Benjamin Hardy and Jonathan P1llsbury are typical merchants and clerks of the commerclal center. The long list of the guests appearing at balls and theater parties impresses the reader with the emphasis placed upon social Iife. 3

Altsheler presents Wijliamsburg as a town in which "the keen commercial atmosphere of New York is missing"

I The Shadow of the North, p. 225 Ibid., p. 225

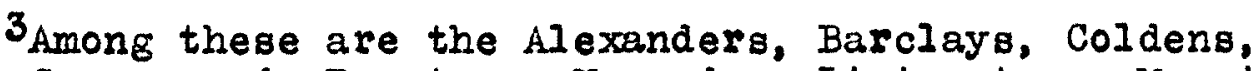
Crugers, de Peyaters, Kennedys, Iivingstons, Morrises, Nicollses, Roosevelts, Van Rensselaers, Waltons, and Wattses 
and where "people talk of politics and the land." He describes it as "a city of only a thousand inhabitants and one street, stralght and wide. $n^{2}$ on this street, he points out the brick buildings of William and Mary, the oldest college in the country, a new capitol buildIng, and the Governor's Palace. It is "a meeting place for the landed aristocracy rather than a commercial centex. $n^{3}$ Ormers of great plantations who come into the town in their high coaches are escorted by black coachmen and footmen in livery. 4 Young men "are Invariably on horseback dressed like English country gentlemen." 5 Typical scenes described by Altsheler are a ball given by the Governor, ${ }^{6}$ a meeting of the House of Burgesses, and $a$ horse race and the dinner which follows. 8 The horse race is attended by the Governor, his wife and

$1-2$

The Shadow of the North, p. 302

3 Ibid., p. 302

4 Ibid., p. 303

5Ibid., p. 303

6Ibid.,pp. 306, 309

Ibid., pp. 309, 310

${ }^{8}$ Ibid., pp. 311-319 
daughters, clergymen, ${ }^{2}$ and "women and girls in their best spring dresses, many imported from London." 2

Altsheler emphasizes the similarity between these Virginla scenes and English country scenes, showing that "here the personal customs and modes of thought of the British gentry have been transplanted." ${ }^{3}$ Contrasting Williamsburg with Bostion, Albany and New York, he shows that "the tie of kinship between the old country and the new seems stronger here than in New England where the England of Cromwell still prevails or in New York where the Dutch and other influences not English are still powerful."

In the last book of The French and Indian War Series, the reader gets a glimpse of Boston, "a town about the size of New York," a town of merchants, shipping men, sailors, and soldiers. There is one scene In a coffee house along the water front and another in the "spacious and pleasing" house of one of the town's leading merchants and warriors. 6 New Inglanders introduced in this scene and in other scenes in these stories

IThe Shadow of the North, p. 312

Ibid., p. 312

Ibid., p. 302

4 Ibid., p. 329

5 The sun of Quebec. p. 204

6 Ibid., p. 204 
are "of purer British blood than those of New York, more strenuous than the Inglish of 0ld England, "and not so nearly English in character as the New Yorkers. They are "critical both of themselves and others and mean to have what they want at any cost."

Against this background of forest and scattered towns and settlements, Altsheler describes important historical events. Being of a military nature, these take place near the forts. A relatively small amount of space is given over to the actual description of them, but each one is used as a climax toward which many chepters have been bullding. For example, the last of the fifteen chapters of The Madow of the North is given over to a degcription of the forest fight of July 9 , 1775, in which General Braddock's army, in its maroh toward Fort Duqueane, is ambushed and destroyed by French and Indians. 2 In this scene, the action in The Shadow of the North reaches its climax. About ninety pages of The Rulerg of the Iakes contain accounts of flghting near Lake George and the battle fought there on september 8,1755 , is described in the last chapter. ${ }^{3}$ In the

The Sun of quebec, p. 204

2 The Madow of the North, pp. 330-337

3 The Rulers of the Iakes, pp. 154-218, 175-177; 312-333 
Wasters of the Peaks, Detween three and four pages are used for the descriptions of the capture of the forts at Oswego by Montcalm on August 15, 1756, and the concluding chapter contains a description of the capture of Fort William Henry by Montcalm in September, 1757.2 The climax of The Iords of the W1Id is reached in the story of General Abercrombie's defeat at Ticonderoga on July $8,1758,{ }^{3}$ which is told in the last chapter. The non-serial, A Soldier of Manhattan, gives an account of the adrentures of Iieutenant Bdward Charteris at this battle and also at the Battle of Quebec on September 12, 1759. The story of this battle, in which the war reached its climax, forms the climax of The Sun of Quebec and of The French and Indian War Serieg.

Altsheler's descriptions of these battles are given from the point of view of his heroes who serve in the capacity of trailers and scouts. One of the most vivid of these scenes is the forest fight in which Braddock's army is destroyed. The story moves swiftly from the

The Masters of the Peaks, pp. 189-192

2 Ibid., pp. 287-311

3 The Lords of the Wild, pp. 256-290

4 The bun of uebec, pp. 303-325 
gay and confident advance of the British army to the horror of the attack and Indian massacre. The story of the capture of the forts at oswego and of the battle at Ticonderoga are told from the point of view of Robert Lennox who is a captive of Jontcalm and so views the preparation for battle and the battles themselves from within the French lines.

The historical characters, William Braddock, Charles Langlade, the Harquis de Montcalm, and Generals Aberoromble and Wolfe are important figures in this scene of warfare. However, they are not as life like as the fictional characters or as those historical characters who are also woodsmen.

The foreground characters in The French and Indian War Series and in A Soldier of Manhattan help to bring the entire American scene before the reader by pointing out the contrasts between its important elements, ${ }^{1}$ by discussing the clains of the contending forces, and by seeking underlying causes for events which are taking place or which may take place in the future.

These characters agree that the elements of the scene which are contrasted with the wilderness and with each other represent the encroachments of the Europeans

1

The Hunters of the Hills, p. 158; The Shadow of the North, p. 198; 302; The sun of Quebec, pp. 203, 204, 205 
upon the land of the lied Wan who "Iighted the first council fires many generations before the French and English came across the seas." ${ }^{1}$ They also agree that there is "plenty of room for Indian, Inglish, and French to dwell side by side." 2 They point out the following inportant contrasts between the French and English and show how they influence the action upon the American stage. The French colonists "adapt themselves more readily than the English to the ways of the Indian. ${ }^{3}$ The French become a part of the wilderness, but the Inglish attempt to conquer it. The French leaders have great skill in handling the Indians, but the english generals fail to undergtand them and their methods of fighting. 6 Treachery is the keynote of the dissolute life in the French court circles at Versailles and

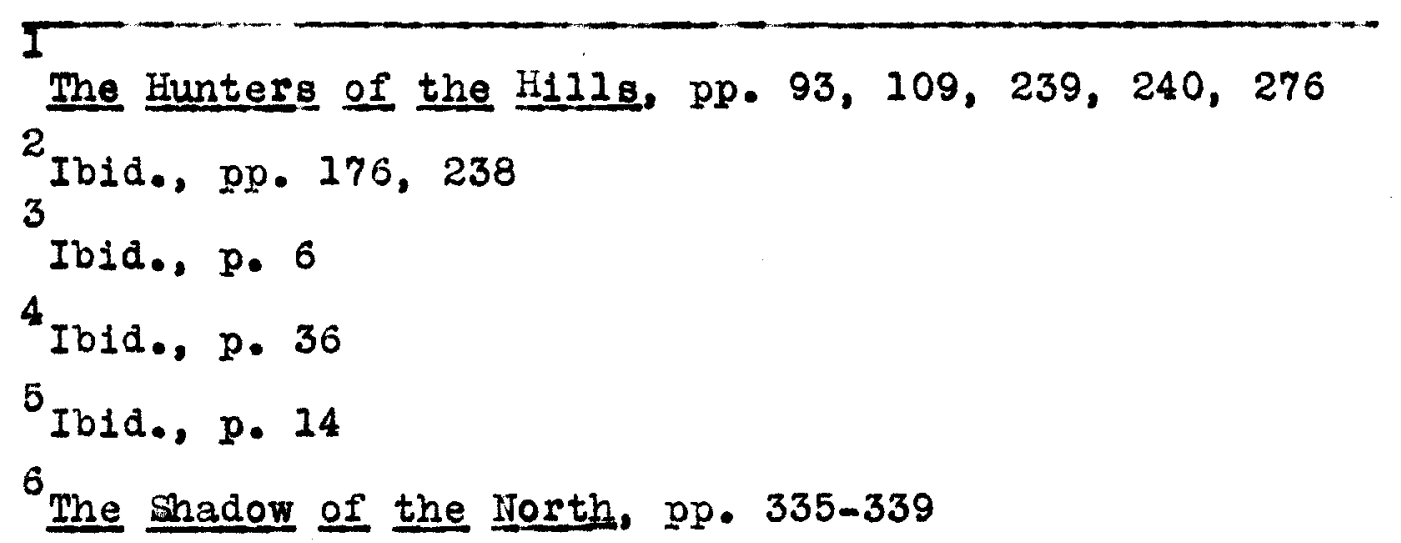




\begin{abstract}
1
Quebec, but the British colonial governors, though inefficient, are blunt and straightforward. ${ }^{2}$ The French colonies "draw their strength and power from the King and the government," ${ }^{3}$ while the British, "left to themselves, grow strong and powerful." 4
\end{abstract}

The strength and power of the British colonies are pointed out as factors which are to have their influence in bringing upon the American stage the scene of 1775 when "this independence will cause trouble to the good British mother." 5

Altsheler's treatment of the American scene at other historical periods follows the above pattern with certain variations. The period of the Revolutionary War is presented in eight books of The Young Trajler Serieg. The author's purpose in The Young Tralles Series was "to present a picture of frontier life and to show the immense hardships and dangers endured by our people as they passed through the wilderness from ocean to ocean." In accordance with this purpose, the $\bar{I}$

The Hunters of the Hi11s, pp. 171, 176, 178, 180, 221, $232, \frac{235}{249}, \frac{272}{272}$

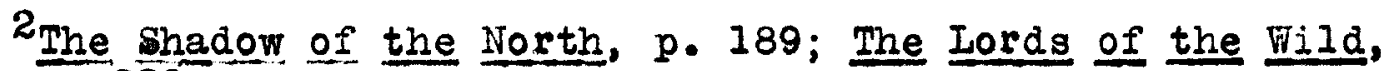
3-4 229

The Hunters of the Hills, p. 31

Iibid., p. 31

6uthor's preface to The Border Watch 
frontier is the element of the American scene which is presented. "The action moves over a wide area, from New Orleans in the south to Lake Superior in the North, and frorn the Great Plains in the West to the land of the Iroquois in the East. ${ }^{2}$ As in The Irench and Indian War Series, the scene unfolds as the duties of the leading characters call them into various parts of the frontier where historical characters, type characters, and historical events are introduced. A discusaion of the treatment of the backwoods of Kentucky will illustrate Altsheler's method of presenting this frontier seene.

He presents the mountains and hills of Kentucky as they appear to the nembers of a wagon train who have come from Maryland and are seeing them for the first time. From the crest of the mountains, they view the wide sweep of rolling country outspread before them. 2 They pass from the mountains into the rolling hills and from there into "one of the richest valleys" which becomes their home." 3 Later, they visit Bif Bone Lick"

Irom the author's preface to The Bordex Watch

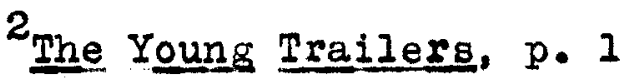

Ibid., p. 16

4 Ibid., pp. 109-159 
is northern Kentucky and explore the cave regions in the southwest. ${ }^{1}$ The scene at $B i f$ Bone Lick is one of his best.

Scenes from the every-day life of these settlers show how they build and fortify the town of Wareville, plant and cultivate their crops ${ }^{3}$, and establish their school, 4 and how they make their own salt and their own gunpowder. 6

Altshelex shows how the fighting along the Atlantic seaboard influenced the lives of these frontier settlers. He does this by introducing into the Kentucky scene an attempt of the Delaware Indians to destroy the settlement of Wareville," the union of the Shawnee and Miami tribes

1

The Young Trailers, pp. 160-170

Ibid., pp. 18-20

3 Ibid., pp. 173-176

4 Ibid., pp. 96-98

5Ibid., pp. 109-125

Ioid., pp. 160-172

I Ibid., pp. 241-310 
against the Kentucky settlements, ${ }^{1}$ and the attempts of the British and Indians to destroy the forts at the mouth of the Licking River and at the Falls of the Ohio. 2 Many of the characters in these scenes are typical frontier settlers. The Ware, Cotter, and Upton families, as well as Tom Ross, Sol Hyde, Braxton Wyatt, and the Rev. Silas Pennypacker represent typical frontier families as well as the typical scouts, renegades, and minister and teacher of the backwoods. Altsheler also introduces into the Kentucky scene the historical characters, Daniel Boone, Simon Kenton, Benjamin Logan, George Rogers Clark, John Floyd, James Harrod, and the renegade, Simon Girty.

Since Kentucky, as well as other parts of the frontler scene, is remote from the seaboard towns, and since this series introduces no character who has a knowledge of world affalrs, there is little discussion of national and international problems.

The American scene of the last decade of the eighteenth century, as presented by Altsheler in The Wildernegs Road, includes the frontier towns of Danville and Iouisville, Kentucky, and Cincinnat1, Ohio; the

\footnotetext{
Ihe Eorest Runners, p. 310

2 The Bordex Watch, pp. 241-248; 273-282; 269-273; 273-327
} 
wilderress of the iorthwestern Territory; and the city of Philadelphia. Danville is described as "the political capital of Kentucky, a sprightly village with some fine houses built of brick brought in wagons over the Allegheneies and with inhabitants who had received the best culture the East could afford side by side with wilderness rovers." I Louisville is mentioned as "a little town by the Falls." 2 Cincinnati is pictured as "a little place in its fifth or sixth year, built of log huts and shanties according to the border fashion of making its beginnings, a picturesque village set between high hills, and with the wide and deep Ohio flowing at its feet." 3 The wilderness of the Northwestern Territoxy is presented as the scene of st. Clair's defeat by the northwestern tribes and of Anthony Wayne's triumph over them. Philadelphia, "our great town", 4 "the heart of our civilization, ${ }^{5}$ is contrasted with the frontier scene. Altsheler peoples the Kentucky scene

The Wilderness Road, p. 174

2 Ibid., p. 26

I Ibid., p. 234

${ }^{4}$ Ibid., p. 359

Ibid., p. 360 
with typical men of the border, "a serlous and solemn race bearing upon its face the stamp of 1ts trials"; with fur traders, lawyers, and Fasterners in proud possession of large land grants; with chiefs and warriors of the northwestem tribes; and with the historlcal characters, Generals St. Clair and Anthony Wayne, Isaao Shelby of Kentucky, and the renegades, Simon Girty and Noses Blackstaffe. When he finds it necessary to bring the political scene into the foreground, he does so by means of the discussions of the borderers who express opinions concerning the seeming inability of the United States government to protect the frontier settlements and concerning the proposed alliance with Spain.

The American scene of 1811-1815 is presented in $A$ Herald of the West, a story in which the leading character travels from Washington to Baltimore, to Philadelphia, to New York, to Boston, to Frankfort, Kentucky, and to New Orleans, witnesses the burning of Washington by the British, and takes part in the Battle of New Orleans. Washington, as a part of this scene, is la raw little city" rising "in spots from wood, bugh, and swamp, ${ }^{2}$ "a lazy capltal of not more than five thousand

1

The Wildermess Road, p. 7

2 A Herald of the West, p. 16 
inhabitants". ' Baltimore is "a great busy city of forty thousand," 2 "a city of brick houses, tall church spires and of sallors who are carrying the name of Baltimore throughout the world." Philadelphia is "a much lareer and finer city than Boston." 4 New York is a city of much business and activity. Boston is "a city of valor, piety, and good business." 5 The great plain of central Kentucky is filled with signs of thrift and abundance-"wheat standing in the fields, fat cattle resting on the banks of the brooks, solid red brick houses, neat stone fences." 6 New Orleans is "a strange, mossy, and beflowered city with high-walled and window-barred houses", a city of Creoles and San Domingans." 7 With this scene as a background, Altsheler brings upon the stage Henry Clay,

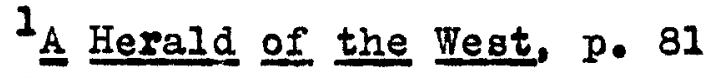

2

Ibid., p. 81

3Ibid., p. 81

4 Ibid., p. 90

5Ibid., p. 168

6Ibia., p. 286

7 Ibid., p. 300 
James Madison, Washington Irving, Thomas Jefferson, and Andrew Jackson. Through the action of the story and through the conversation of the characters, he presents the causes which brought about the War of 1812 and the attitude of each section of the country toward it. He describes the burning of Washington and uses the Battle of Wew Orleans as the climax of the story.

In the three books of the Texan Series, Altsheler presents three phases of the Texan struggle for freedom. The scene of the firat phase shifts from the city of Mexico to San Antonio, Texas, the seat of the kexican power in the north; that of the second phase is the plains of southern Texas and at the Alamo; and that of the third phase moves from the Colorado to the Brazos and from there to san Jacinto. Important battles which took place during the Texan struggle are carefully described. Typical Texan fighters and typical Mexican generals, soldiers, and peasants are introduced and the attitudes and opinions of both Hexicans and Texans are discussed by the characters.

The period of the War with Hexico is presented in The Quest of the Four and the scene moves from New Orleans westward to Santa Be, across the Rlo Grande into Wexico, to the Battle of Buena Vista, and westward 
toward Califorria. General Zachary Taylor and his men, typical Mexican generals and soldiers, and bands of Comanche Indians have their places in this scene.

The Civil War Period is presented in the eight books of The Civil War Series which opens with a glimpse of the every-day life in Pendleton, Kentucky. This is na town of fifteen hundred people, important in its section as a market and as a financial and political center." ${ }^{l}$ The calm of the village scene is broken by the news of the secession of South Carolina and the center of interest moves to Charleston where "citlzen soldiers are drilling in open places and other men are throwing up earthworks" 2 and where the firing upon The Star of the West occurs. The scene shifts to Nontgomery on the day when Thomas Jefferson is inaugurated as president of the Confederacy, 4 and from there to Irankfort, Kentucky, at the time when the opposing forces in the legislature are fighting for the State's allegiance. After that, the two Kentucky boys who are heroes of the stories join opposing forces and the scene moves from battlefield to battlefield according to the activities of the Army of the Potomac,

\footnotetext{
The Gune of Bull Run, p.7

2Ibid., p. 49

3 Ibid., pp. 75, 76

Ibid., pp. 92-104
} 
the Army of Northern Virginia, and the Northem and Confederate arnieg in the West. Twenty-six important battleg are described and thirty historical characters are introduced into the scene. Northern and Southern points of view and underlying causes of successes and failures are brought to the reader's attention through the conversations of citizens and soldiers.

Altsheler's representation of the American scene of 1866--1890 is made up of glimpses of the great West. The scene of The Great West gerieg is the land of the Sioux in the northwest in 1866. The second of the two books of this series is almost entirely made up of the picture of life among these Indians. The non-serial, A Horsemen of the plains, gives a picture of the southwest between 1866 and 1869. The scene moves from Omaha to the beaver country in the Rocky Mountains and from there to the battle fields of the Cheyenne war at Washita and on the Arickaree. Apache Gold gives a picture of the high mountains, abandoned cliff dwellings, and fierce Apaches of the southwest. The action of The Iast of the chiefs takes place on the Great plains and in the Rocky Mountains and reaches its climax in General Custer's final defeat of the sioux Indians in 1876. 
In his treatment of the American scene, Altsheler has given a panoramic representation of large events and has included glimpses of American life at different historical periods and in many sections of the country. However, his chief interest has been in the western frontier and he has given much space to the representation of border Iffe and to the discusgion of events which have resulted in pushing the frontier steadily westward. His picture of the American scene is an optimistic one. His leading characters succeed in their undertakings and are not sensitive to the dism comforts and sufferings of the frontier and battlefleld. Great struggles are represented as being those with Right on their side. "All will come out right in the end," is Altsheler's theme as he interprets the scene. 


\section{Chapter Jour}

Ideolooy Fxpressed in Altahelex's stories 
Ideology Expressed in Altsheler's Stories

The ideology expressed in Altsheler's stories has been implied in the discussion of his characterlzation, his story-telling, and his presentation of the American soene. At the center of this ideology is the belief In the organization of the world upon the princlple that, in every struggle, the Right ultimately prevails. The stortes express a conception of the Deity as a spirit which guards and guides those who are champions of the Right, and a conception of Nature as the friend and aldy of the man who loves and understands her. According to this ideology, man's duty in the universe Is to act as the defender and champion of those things which he believes to be honest and just. There 1s, in the stories, much emphasis upon the desirability of the outdoor Iife, as well as upon the value of leaming and culture. The qualities emphasized in men and women are intelligence, resourcefulness, strength of will, loyalty, couraze, optimism, courtesy, chivalry. There Is no emphasis upon discouragement, fallure, or hopeless suffering; and the sordid slde of life is never presented. The love stories are idyllic and serve to emphasize the chivalxy of the heroes and the beauty, 
intelzigence, and courage of the heroines.

It was mentioned in Chapter Three of this thesis that Altsheler represents the American scene as one which proves that "all will come out right in the end." "

The characterization and story telling, too, euphagize the ultimate triumph of the Right. The nature of the characterization makes it possible for the story telling to illustrate the operation of thio principle in the lives of individuals. The heroes, as mentioned in Chapter One ${ }^{2}$, are young men whose loyalty, generosity, and chiraly naturally place them on the side of Right, Justice, and Honor. With fer exceptions, the antagonists againgt whom these heroes prevall are unscrupulous, treacherous, cruel, and dis1oyal. The triumph of Robert Lennox over Achille Garay $^{3}$, of David Willet over Adrian Van Zoon ${ }^{4}$, of Tayoga over Tandakora". of Henry Ware orer Braxton Wyatt $^{6}$, of Edward Bulton over Irancisco Urrea?, of

1

Chapter Three, page 99

2 Chapter One, page 40

3-4-5

The Irench and Indian War Series

6 The young Trailer Series 7

The Texan series 
John Scott over Fernand Weber ${ }^{2}$, and of Robert Horton over Juan Carrer ${ }^{2}$, are a few examples of Altsheler's use of the triumph of chivalry orer selfishness, of loyalty over disloyalty, of sincerity over treachery. and of knowledge and skill over cunning and decelt. The stnry told in The Wildernegs Road is another interesting illustration of Altsheler's method of showing that Right ultimately triumphs in the lives of individuals. The hero, John Lee, has been a lieutenant in the American army during the Revolutionary War. He has been accused and convicted of plotting with the enemy. He hav fled into the wilderness and, with dishonor reating upon him, he has served his country for fifteen years. At the time of the opening of the stnry, he joing st. Clair in his expedition against the tribes of the Northwest. He serveg as a trailer and scout, saves pioneer villages from capture, and effects the rescue of Americang captured by Indians. After fifteen years, his accuser and antagonist perlshes as the victim of savage allies toward whom he has acted the part of traitor. Soon after this, as a result of an investigation conducted by the girl

${ }^{1}$ The World War Series

$Z_{\text {The Horgemen of the Plains }}$ 
who is in love with him, John Lee's innocence is proven and he is publicly restored to his place of honor in the nation. The investigation also shows that it was Lee's antagonist who committed the crime of which the hero was convicted. Every Altsheler story furnishes similar illustrations of the triumph of the noble characters over the ignoble ones and serves as a vehicle for the doctrine of "poetic justice."

In his story-telling and in his presentation of the American scene, Altsheler illustrates the operation of this same principle in the affairs of nations. The contrasts between the Inglish and French which he points out in The French and Indian War Series have been discussed in this thesis. ${ }^{2}$ These contrasts prove the ouperior fitness of the formex for the task of building a new civilization on the American continent. They thus establish the fact that it is right that the Eng11 sh be the victors and that the Altsheler heroes succeed in the tasks which they undertake in their behalf. In A Herald of the West, Altshelex presents the unjust impressment of Amexican seamen in many scenes. 2 He thus makes it evident that the declaration of war and

${ }^{1}$ Chapter Three, 88-89

2 A Herald of the Weat, pp. 144-145-146-147-148-149$\overline{15} \overline{0-152-1} \frac{190}{40}$ 
the ultimate success of the Americans in the second war with Great Britain are right and Just. Again, in The Texan Series, the treacherous imprisonment of Austin and the attempt of Santa Anna, through bad faith, to disarm the Texans and leave them at the mercy of the Indlans establish the right of the Texans to rebel against Wexican rule. Thus, he prepares the reader to view the success of the Americans in the Wax of 1812 and of the Texans in their struggle for liberty as examples of the triumph of the Right. The War with Mexico, the World War, and the wars against the Indian tribes are handled in the same manner. Four books of the Civil War serieg are written from the Southern point of view and four from the Northern. ${ }^{2}$ But similarities, rather than differences, between the people of the two sections are emphasized and the reader is never allowed to forget that he is viewing a great internal struggle. He is thus prepared for a scene in which two southern officers, discussing General Lee's surrender, agree that the war has ended in the way which is for the best. "With the North reannexed, the Union will soon be stronger and more prosperous than ever," says one. And the other replies, "WeIl spoken, Hector. Well spoken. It is 
pexhaps better that North and South remain together. I thought otherwise for four years, but now I seem to have another point of view." And they drink "to the health of the common country. ${ }^{1}$

In this universe where Right prevails in the lives of individuals and in the affairs of nations, the spirit which is the White Man's God and the Red Man's Manitou guards and guides those who are allied with the Rlght. Whispered warnings of spirits of the ais prevent the death or capture of those who carry important messages and guide the progress of rescuing parties. In every story, the heroes give to a guarding and guiding Providence the credit for the marvelous feats which they perform and for their miraculous escapes from danger. However, there is a strong emphasis upon the fact that man can expect no divine ald except in worthy undertakIngs which require great labor and much courage. Man1tou, when he is displeased, turng his face away. When man has been sufficiently punished for his wrong doing, he may expect the Deity to smile upon him.

One of the many illustrations of this relationship between man and the Deity is found in The Masters of the Peaks, the fourth story of The French and Indian

The Tree of Appomattox, p. 302 
War series. This story is concerned with the work of Robert Lennox, Tayoga, and David Willet as they attempt to gain, for the English leaders, information concernIng the plans of the French. The beginning of their task is marked by an interval of desperate struggle to preserve their own lives. For forty-eight hours they battle against cold and starvation. In their efforts to escape from a French war party, they spend a terrible night journeying through cold and sleet from a mountain summit to the valley and back again to the aumit. DurIng this time, they feel certain that, in some way, they have displeased Manitou. They are unable to determine what their sin has been, but when at last they succeed in finding food, their triumph over starvation indicates to them that they have atoned for their wrong doing.

In The French and Indian Tar series, much use is made of the belief of divine guidance through the agency of "roices of the air." Tododaho, the patron saint of the Iroquois, sits upon his star and sends to the young chief, Tayoga, messages of wamings, promises of good fortune and success, glimpses of the ultimate fate of his enemies, and visions of the honor and gloxy which are to come to him and to his friends. Robert 
Lennox, the American boy, listens while Tayoga translates these messages from the air and he is so impressed by Tayoga's sincerity that the Indian belief becomes his own. When he becomes a solitary prisoner on an uninhablted island, be, too, listens to the roices of the air which warn him when danger approaches and give him the promise of rescue by friends. An entire chaptex of The sun of Quebec is concerned with these usterlous whisperings.

The conception of Nature as a friend of the man who is in sympathy with her and is on the side of Right is Implied in their belief in the spirits of the alr as agents of a guarding and guiding Providence. The same conception is evident in the numerous instances where storms on land or on rivers, lakes, or ocean become the agents of Providence in bringing about the triumph of the Right. One such instance occurring in The Young Trailers enables a group of frontieramen to escape from a beselging party of shawnees. Escaping, they feel "a deep and devout thankfulness for the chance that has saved them from a long seige and possible death; Indeed it seemed to them that the hand of God had turned the enem aside. ${ }^{1}$ " There are ingtances

The Young Trailers, p. 152 
where storms on lakes and rivers enable heroes to escape from pursuing savages. Storms and shipwreck on the ocean enable heroes to escape from their captors. Timely delay of battles and rescue of captives result from fog on lake and river. In another instance, the capture of an enem fleet is effected during the halfhour during which the sun is in eclipse. The rescued captires, the escaping frontiexsmen, and the captors of the fleet are flghting for the cause represented in the stories as being the Right.

Not only are the forces of Nature allied with men who are fighting for the Right, but man "feels his kindred with the little people of the forest." ${ }^{2}$ Birds and animals become the friends and allies of trallers, scouts, and warriors who are helping to hasten the westwayd march of civilization. The opening chapter of The loxdg of the Wild telis the story of a blue bird which gives warning of the approach of danger and guides the hero to a place of safety and to success in hia undertakings. Henry Ware of The Young Trailer Series was "a primeval son of the forest" ${ }^{2}$ to whom Nature spoke words of friendship, hope, or warning. In the songs

The Keepere of the Trail, p. 102

Ibid., p. 101 
of the birds, he read a message which told of the temporary absence of enemies and the sudden cessation of their music warned him of the approach of danger. ${ }^{2}$ Iike the Indian, he understood the language of a friendly Nature.

The men who achieve happiness in this world where Right prevails and where Providence guides and directs and expresses itself through Nature are those who devote themselves wholeheastedly to those undertakings which they belleve to be right and just. This idea of man's place in the world is emphasized in the characterization of all of the Altsheler heroes and in theis action in the stories. The heroes of The French and Indian War series act as the bearers of messages in the interest of prevention of war, they secure alliances which wlil benefit the Ingligh whom they believe to be in the right, they save the inhabitants of a remote fortress from horrible Indian atrooities. The heroes of The Young Trailerg and of The Hilderness Rogd act as friends and protectors of emigrant trains and of remote settlements. The Texan leaders and the heroes of The quest of the Foux devote all of their enexgies to the rescue of their countrymen from the oruelty and infustice of the Mexicans.

${ }^{1}$ The Keeperg of the Tra11, pp. 2; 102-105; 270; 323 
The heroes of the War of 1812 enliat the ald of theis oountrymen in fighting against cruelty and infustice. The heroes of the western stories promote the spread of oivilization toward the Pacific coast. In The civil War Series, foreground figures and historical characters serve with devotion the causes in which they believe. The heroes of the love stories are young men who fight for principles in which they believe and perform deedo of chivalry which bring happiness to the heroines. John Iee of the Wilderness Road risks his life in effecting the rescue of a Philadelphia girl, Rose Carew, from the Shawnee Indians. John Kingsford of In Clrcling Camos risks hls own life in order to save his sweetheart, IIInox Maynard, from a cruel conspiracy. John scott of The World War Series vallantly rescues Julie Lannes, a Parisian girl, from her Gexman captors. In seeking the way of life which this ideology suggests, the readex is impressed by the strong preference for out-doox life. Many of the heroes are hunters, scouts, and trallexs. Three-fourths of the scenes represent the deep wilderness or the small frontier gettlements. The characters are persons to whom the forest is a kingdom and who learn great wisdom through their life on the frontier. Kany of them prefer the 
Iife of the forest to that of the city. Upon leaving Quebec, Robert Lennox, David Willet, and Tayoga welcome the great northern wilderness as their home and feel safer there than among the dangers which have surrounded them in the French capital. Henry Ware of The Young Trailer Series thinks of his life in the Wareville settlement as martydom ${ }^{1}$ and, at the first opportunity, escapes from it into the forest which "seems to reach out. its boughs like kind arms to welcome and embrace." ${ }^{2}$ Yet the Altsheler stories do not express the "back to Nature" ideology of Rousseau. Many of the finest characters are people of the towns and cities and there Is much emphasis upon the importance of learning and refinement. David Willet, who is responsible for the training of Robert Lennox, is careful to instruct him in all of the lore of the wilderness and in all of the skills of the woodsman, scout, and traller. But he is not satiafied for the young man to become an ordinary backwoodsman, unfamiliar with the ways of civilization. He gives him the adrantage of attendance at the best

Ime Youns Ira1lers, p. 316 
sohool in Albany and of living in one of its most cultured homes. In addition to this, he instructs him in the 01d World culture which has been a part of his own experience and training. The result is that the young $\operatorname{man} i s$ in no sense inferior in brilliance, cleverness, courtesy, or grace to the cultured Frenchmen with whom he afterward comes in contact. Many other Altsheler heroes are "the products of the combined influence of the settlement and the foregt." ${ }^{2}$

Wile many of the Altsheler heroes are soldiers and whlle all of his stories pextain to warfare, the ways of peace are emphasized as being the more desirable. It is repeatedly suggested that the way of life in the merchant cities of New York and Albany and in Williamsburg of agricultural Virginia is to be preferred to that of military quebec. In the Civil War Serieg, emphasis is placed upon the readiness with which Northern and southern soldiers return to their peace-time occupations aftex Lee's surrender.

In Altshelex's treatment of the Clvif, War, we find the pragmatist's evaluation of ideas according to their degree of success. But, in the main, his philosophy

${ }^{1}$ Chaptex One, p. 40 
is Idealistic.

The way of life which is ldealized in the Altshelex stories is the way of iffe of the Boy scouts, and the Altsheler heroes are typlcal Boy scouts seen against a background of historical incident. They share the Boy soout's ideals of patriotism, chivalny, and courage. They possess the physical prowess, cleverness, and sk111 which the life of the outdoors develops. Theis understanding of Nature and her ways has led them to think of her as a friend to man and they believe that those causes which are right and just must ultimately preva11.

The standard set up for Boy Scouts of America 1s that they be "considerate individuals, having reverence for sacred things: each one able to take care of himgelf in an emergenoy, each one taught to be a leader and able, when necessary, to take command." ${ }^{2}$ Measured by this standard, Altsheler's heroes are good scouts. The scout idea was inspired by the real American scouts, such as Boone and Carson" ${ }^{2}$ and Altsheler has put into his books a large number of these "real American scouts," while the heroes of his books are younger Amexloang who "IIve the adventuroug 11 fe of the border and emulate the honor, honesty, and virtue of the old scouts. 3

$1.2-3$

Dan Beard: National Scout Cormissioner, Boy Scouts of America (In The Mentos-August 1927) 
Conclusion

Altsheler's Contribution to Boys' Fiction 


\section{Conclusion}

Altgheler's Contribution to Boyg' Hiction

First, Altsheler has written good action stories and has brought a well-constructed plot into the boys' serial.

Second, he has conveyed a vivid sense of American life in the past.

Third, he has made his stories vehicles for Boy Scout idealigm. He has enabled his readers to identify themselves with a hero who is a Boy scout in the image of the old frontier woodman.

Fourth, his most important contribution to boys' fiction is the love of nature and the senge of the moods which he has put into every one of his stories. Writing to appease his own homesickness for his boyhood experiences in the Kentucky woods, he has put into his stories the memory of these experiences and has caught up with them the stories of settlement life and the legends about the old scouts which had been told to him by his mother. His wilderness scenes are the best parts of his books, and boys, having read his stories, return to these vital spots and read them over and over. 
As Dan Beard's mission was to take the city boy into the open, Joseph Altsheler's mission was to bring to the modern American boy the strength, beauty, and peace of the wilderness of the old frontier. 
B1bliography

118 


\section{Bibliography}

\section{General}

Beach, J. W., The Twentieth Century Novel, D. Appleton-Century Company, New York, 1932

Cotterill, Robert Spencer, History of Pionoex Kentucky, Johnson and Hardin, Cincinnati, 1917

Hatcher, Harlan, Creating the American Noted. Farrar and Rinehart, New York, 1935

Van Doren, Carl, The American Novel, McMillan Company, New York, 1921

Van Doren, Carl, Contemporasy American Novelists. MoMilian Company, New York, 1922 
II Discusgions of Jurenile Fiotion

A. Books

Bennett, James O'Donnell, Much Loved Books, Boni and Leveright, Hew Yoxk, 2927

Dickinson, Thomas Herbert, The Making of American

Itterature, The Century Company, New York, 1932

Barle, Mrs. Alice Moore, Child Iife in Colonial Davs, McMilian Company, New York, 1899

Goodrich, Samuel G., Recollections of a Ilfetime, Miller, Orton, and Nulligan, 1856

Halsey, Rosalie Vrylina, Forgotten Books of the American Nurgery or A History of the Development of the American Story Book, Charles E. Goodspeed and Company, Boston, 1911

Kunitz, Stanley J. and Haycraft, Howard, The Junior Book of Authorg, H. W. W1lson, New York, 1934 
Noses, Montrose Jonas, Chlldren's Books and Readins, M. Kennerley, New York, 1907

Mott, Frank Iuther, A History of American Magazines, Appleton, Wew York, 1930

Smith, Elva 8., The History of Children's Iiterature, American Iibrary Association, Chicago, 1937

Weeks, Blanche B., Ilterature and the Ch11d, S11ver Burdette Company, New York, 1935 
B. Magazine Articleg

Anonymous, "Books for Children", Quarterly Review, 71 (Dec. 1842) 54-83

Anonymous, "Children's Books of the Year," The North American Revier, 102 (Jan. 1866) 236-49

Beard, Dan. "The Scout--Boy and lan", Mentor (Ag. 1927) 15-22

Heyliger, William, "Finding the Highway", The Horn Book Magazine, 10 (Sept. 1934) 307-312

Ives, Vernon, "The Night Before Christmas," The Horn Book Magazine, 13 (Hov. 1937) 538-43

Jordan, Alice $K_{.}$, "The Children of Jacob Abbott," The Horn Book Nagazine, 20 (1934) 221-227

Jordan, Alice 15., "Peter Parley", The Horn Book Marazine, 10 (1934) 96-101 


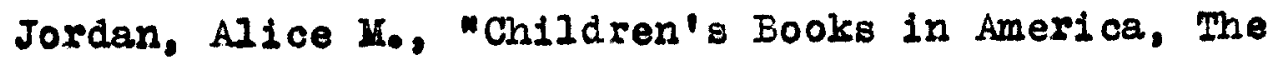
Pirst Two Hundred Years," The Horn Book Marazine, 10 (Jan. 1934) 9-19

Hoore, Annie Carrol1, "The Creation and Criticlam of Children's Books," The American Ifbrary Association Bulletin, 28 (1934) 693-701

Presbrey, Frank, "American Boy Scouts", Revier of Reviexs, (June, 1931)

Report of Annual Heeting of the Amexican Iibrary Association in Chicago, News-Week (Jan. 11, 1916)

White, HIza Orne, "Some New Fngland Authors and Their Storiea," The Horn Book Marazine, 10 (Jan. 1934) $11-21$ 


\section{Boys' Hiction}

Abbott, Jacob, The Iranconia Storles, Harper Bros., New York, 1881

Alcott, Louisa May, Little Hen, Iittle-Brown Co., Boston, 1901, Jolg Boyg, Ilttle-Brown Co., Boston, 1902

Aldrich, Thomas Bailey, The Story of a Bad Boy, Houghton Mifflin Co., Boston, 1897 (First published in "Our Young Folks," Jan. to Dec. 1869)

Alger, Horatio, Jr.,

The Store Boy, Donohue and Co., Chicago, 1889 Bound to Rise, Donohue and Co., Chicago, 1890 Brave and Bold. Donohue and Co., Chicago, 1889 Iry and Trust, Donohue and Co., Chicago, 1890 Altsheler, Joseph Alexander ${ }^{2}$

${ }^{1}$ See complete list of Altsheler's fiction, pp. 128-13? 
Appleton, Victor

Tom Swlft and H1s Motorarcle, Grosset and Dunlap, Now York, 1910

Tom Swift and His Air Glider, Grosset and Dunlap, New York, 1912

Barbour, Ralph Henry, For the Honor of the school,

D. Appleton Company, New York, 1905

Bird, Robert Montgomery, Wick of the Woods, A. I. Burt Company, New York, 1905

Burritt, Rdwin C., The Bor Scout Crusoes, Fleming H. Revell Company, New York, 1916

Churchill, Wington, The Crossing, MoMillan, New York, 1904

Clemens, Samuel Langhorn

The Adventures of Tom Eawrer, Harper Bros., Niew York, 1903 The Adventures of Huckleberry Finn, Harper Bros., New York, 1904

The Prince and the Pauper, Harper Bros., New York, 2901 
Coffin, Charles Carlton, The Boys of 176, Harper Bros. New York, 1876

Cooper, J.F.,

The Deerslayer, Nolulilan Company, New York, 1904

The Pioneer, Mollizlan Company, New York, 1901

The Iast of the Mohicans, Houghton, Boston, 1898

Crane, stephen, The Red Badge of Courage, Appleton, New York, 1895

Doubleday, Russe11, Cattle Ranch to College, Doubleday, New York, 1899

FI11s, Edward 5., Ned on the Rlver, Henry T. Coates and Co.. Philadelphia, 1884

Fox, John Jx., The Ifttle ghepherd of Kingdom Come, Scribner's, New York, 1903

Heyliger, Wi1liam, Don Strong of the Holf Patrol, Appleton C0., New York, 1916 
Hubbard, Ralph, Queer Person, Doubleday Doran Co., New York, 1930

James, W111, Iook--See With Uncle Ben, Scribnex's, New York, 1938

Kelly, Eric P., Three Sides of Agiochock, McMilian, New York, 1935

Hunroe, K1rk, Hamingo Feathex, Harper, New York, 1905

Ot18, James, Toby Tylex, Harper, Ner York, 1880

Seton, Ernest Thompson, Two Little Savages, Doubleday Page Co., Hew York, 1903

Wite, Stewart E.,

The Riverman, McClure Co., New York, 1908

Danfel Boone, Wilderness Scout, Doubleday Page Co., New York, 1922

Winifred, Arthur, The Rover Bors on the River, ChattertonPeck Company, New York, 1905 
IV Fiction by Joseph A. Altsheler

A. Hovels Intended for Adults

(Publishers, D. Appleton-Century Company, New York)

The Sun of Saratoga

1897

A Soldier of Manhattan

1897

A Hereld of the Weat

1898

The Last Rebel

1899

In Circling Camps

1900

In Hostile Red

1900

The Wilderness Road

1901

Mr Captive

1902

Before the Dawn

1903

Guthrie of the Iimes

1904

The Candidate

1905

The Recovery

1905 


$$
\begin{gathered}
\text { B. Hlstorlcal Romances for Boys } \\
\text { (Publisher, D. Appleton-Century Company, Hew York) }
\end{gathered}
$$

The Young Trailers

1907

The Forest Runners

1908

The Iree Ransers

1908

The last of the chlefs

1909

The Riflemen of the ohio

1920

The Horsemen of the Plains

1910

The Scouts of the Valley

1911

The Quest of the Dour

1911

The Border Watch

1912

The Texan Star

1912

The Texan Scouts

1913

The Texan Triumph

1913

Apache Gold

1913

The Guns of Bull Run

1914

The Guns of Shilon

1914

The scouts of stonewall

1914

The Sword of Antietam

1.914

The Star of Gettrsbura

1915

The Rock of Chickamauqua 
The Guns of Europe

The Forest of Swords

The Hosts of the A1r

1915

The Shades of the Wilderness

1916

The Eeeperg of the Trail

1916

The Tree of Appomattox

1916

The Hunterg of the Hi1lo

1916

The Ehadow of the North

1917

The Eves of the Woods

1917

The Rulers of the Iakes

1917

The Masters of the Peaks

2918

The Great Sioux Trail

1918

The Lost Hunters

1918

The Iords of the Wild

1929

The Sun of Quebec 
C. Short Stories

"After the Battle," Lippincott's, 61 (1898) 379-88

"At the Twelfth Hour: A Tale of a Battle", Atlantic Monthly, 82 (1898) 541-58

"The Governor's Choice," Iippincott's, 70 (Ag. 1902) $265-76$

"Iscape," Harper'g Weekly, 47 (June 6, 1903) 940-2

"Dawn in the Desert," Harper'g Weekly, 47 (JI. 25, Ag. 1, 7903) 1236-9, 1272-4

"Jimny Grayson's SpelI", Harpex's Weekly, 47 (Ag. 16, 1903) 1344-8

"Third Degree", Haxper's Weekly, 47 (Ag. 22, 1903) 1380-4

"Dead City", Harper's Woekly, 47 (Oct. 24, 1903) 1712-6

"Island Chute", Haxper's Weekly, 47 (Dec. 12, 1903) 1972 
"Wedding Guest," Haxper, 107 (Oct. 1903) 668-74

"Spellbinder," Harper's Weekly, 48 (Oct. 1904) 2664, $1666-7,1679$

"Retreat of the Ten," Cosmopolitan, 38 (Nov. 1904)/33-42 


\section{Iife}

I was born in shelbyville, Kentucky, and attended Selence Hill school through the elementary grades and High school. I received teacher training at the Western Kentucky Teachers' College in Bowling Green, finishing the two-year course in 1920. I attended the Louigville Conservatory of Music for three years, graduating from the Dramatic Art Department in 1925. In 1930, I recelved the degree of Bachelor of sclence in Education from the University of Louisville.

since 1920, I have been a primary teacher in the public schools of Loulsville. In addition, I taught dramatios in the Louisville Conservatory of Music during the school year 1925-26.

In 1935, I contributed serenteen storles to the third and fourth books of the series of readers called The Iriendly Hour Readerg. ${ }^{1}$ I collaborated with vary Browning in writing the workbook ${ }^{2}$ and teachers' manual ${ }^{3}$

The Friendly Hous Readers, Leavel1, Breckinridge, Browing, Fol118, American Book Company, New York, 1935 2

Workbook for The Friendit Hour, Book Three, Browning, and Demaree, American Book Company, New York, 1935 3 Teacherg' Yanual for The Irlendy Hour, Book Three. Browning and Demaree, Amexican Book Company, New York, 1937 
for Book Three of this series.

During the last seren years, I have been teaching in the George Rogers Clark school in Cresoent Hill, Louisville. I have been espeolally interested in children's reading. Observing the popularity of Altsheler's fiction, I sampled the interest of two hundred and fifty boys and girls in these books. Response to my questionnaire showed that in 1937 seventy-five per cent of the boys and twenty per cent of the girls between the ages of eleven and thirteen were Altsheler readers. The Young Trailers was found to be the most popular series. It was shown that the appeal of the Altsheler books is due to their tales of the adventures of "admirable heroes" and to their pictures of life in the backwoods and in the frontler settlements. 